\title{
The Sandstone Quarries of the Angkor Monuments in the Southeastern Foothills of Kulen Mountain
}

\author{
Etsuo Uchida', Ryota Watanabe', Motoki Murasugi', Yuichiro Sakurai ${ }^{1}$, Ichita Shimoda ${ }^{2}$ \\ ${ }^{1}$ Department of Resources and Environmental Engineering, Faculty of Science and Engineering, Waseda University, Tokyo, Japan \\ ${ }^{2}$ World Heritage Studies, Graduate School of Comprehensive Human Sciences, University of Tsukuba, Ibaraki, Japan \\ Email: weuchida@waseda.jp
}

How to cite this paper: Uchida, E., Watanabe, R., Murasugi, M., Sakurai, Y., \& Shimoda, I. (2020). The Sandstone Quarries of the Angkor Monuments in the Southeastern Foothills of Kulen Mountain. Archaeological Discovery, 8, 207-227. https://doi.org/10.4236/ad.2020.83012

Received: April 19, 2020

Accepted: May 12, 2020

Published: May 15, 2020

Copyright $\odot 2020$ by author(s) and Scientific Research Publishing Inc. This work is licensed under the Creative Commons Attribution International License (CC BY 4.0).

http://creativecommons.org/licenses/by/4.0/

\section{Open Access}

\begin{abstract}
The Angkor monuments in Cambodia were designated as a UNESCO World Heritage Cultural Site and consist of Buddhist or Hindu temples built mainly of sandstone and laterite. We surveyed the area around a $2 \mathrm{~km}$ east-west bank in Kulen Mountain's southeastern foothills for Angkor's sandstone quarries and confirmed 145 locations. Because the magnetic susceptibilities and size of sandstone blocks at Angkor changed systematically over time, we measured these aspects at each quarry. Based on this data, we identified seven Angkor quarrying areas (Areas $A$ to $G$ ). The results clarified that in the Angkor period, sandstone block quarrying began near the bank's eastern end, then moved counterclockwise to the north side of the bank. Because quarries are important Angkor period heritage sites, they should be designated as conservation areas for their protection.
\end{abstract}

\section{Keywords}

Angkor Monument, Sandstone, Quarry, Kulen Mountain, Cambodia

\section{Introduction}

As one of the world's largest pre-industrial cities, Angkor is among Cambodia's most important archaeological sites. Located in the current Siem Reap Province, it consists of monuments constructed between the $9^{\text {th }}$ and $15^{\text {th }}$ centuries AD (hereafter, assume all dates are $\mathrm{AD}$ ). Studying the temples' construction materials has led to several key findings. While some $9^{\text {th }}$ to $10^{\text {th }}$ century Angkor temples contained bricks, sandstone and laterite were the primary construction materials used. The Angkor monuments contain three types of sandstone: gray-yellowish 
brown sandstone (feldspathic arenite), red sandstone (quartz arenite), and greenish graywacke (feldspathic wacke) (Uchida et al., 1998).

Different usage of the three sandstones suggests various levels of importance. The Banteay Srei temple, for example, was built mainly of red sandstone; few red sandstone blocks were found among gray-yellowish brown sandstone blocks at late Bayon period or later temples (the $13^{\text {th }}$ century). Greenish graywacke was only utilized in five sanctuaries on the top of the Ta Keo temple (Uchida et al., 1998) but was frequently used for statues and Hindu Linga-Yoni sculptures. This suggests that despite the infrequent usage, greenish graywacke was an important stone for the Angkor monuments. Meanwhile, gray-yellowish brown sandstone was present in every temple, used even in the Banteay Srei temple in its entrance, window frames, and lattice windows; therefore, this sandstone was the most important found in the Angkor monuments.

Gray-yellowish brown sandstone is widely distributed in eastern but not western Cambodia; it can also be found in Vietnam, Laos, and around the Khorat Plateau in Thailand (Tien et al., 1990; Mantajat \& Hinthong, 1990). It was commonly used in large-scale temples, such as the Angkor, Beng Mealea, Koh Ker, Preah Khan of Kompong Svay, and Banteay Chhmar temples in Cambodia as well as the Wat Phu temple in Laos (Uchida et al., 2010, 2013, 2014). In Cambodia, this material is produced from the Terrain Rouge Formation (ESCAP, 1993); in Thailand, it is called the Phu Kradung Formation (Meesook et al., 2002). The formation has recently been classified as of the Late Jurassic to Early Cretaceous (Meesook, 2011).

The chemical and mineral composition of the gray-yellowish brown sandstone is homogenous throughout the Angkor temples (Uchida et al., 1998). However, the sandstone's magnetic susceptibility varies depending on the construction period (Uchida et al., 1998, 2003, 2007). Based on the Angkor blocks' magnetic susceptibilities, Uchida et al. $(1998,2007)$ predicted that there were seven quarries (quarrying areas) used during the Angkor period. The gray-yellowish brown sandstone production area closest to the Angkor monuments is located in Kulen Mountain's southeastern foothills, about $30 \mathrm{~km}$ northeast of the Angkor area. Garnier (1873) and Delaporte (1880) first reported on these quarries while Delvert (1963) and Boulbet (1979) presented a rough distribution of sandstone quarries. Carò and Im (2012) and Uchida and Shimoda (2013) recently conducted detailed surveys.

Uchida and Shimoda (2013) revealed 56 quarries' locations. They estimated the period when the sandstone blocks were removed based on their magnetic susceptibilities and the step heights of the sandstone quarries. Upon examining Areas A to G deduced by Uchida et al. (1998, 2007), Uchida and Shimoda (2013) indicated that quarrying Areas $\mathrm{C}$ to $\mathrm{G}$ had moved over time. Additionally, they revealed the transportation route for the sandstone blocks from Kulen Mountain. Evans (2016) determined the sandstone quarries' distribution using airborne laser scanning of Kulen Mountain's southeastern foothills but has not 
presented detailed data. We expected to identify additional quarries and continued investigating them to clarify the distribution area and quarrying period. We report the results here.

\section{Methods}

Uchida and Shimoda (2013) utilized Google Earth to reveal the existence of a 2 $\mathrm{km}$ bank along Kulen Mountain's southeastern foothills. They speculated that the bank is related to the transportation of sandstone blocks due to a canal connecting the quarrying area to the Angkor area along the southwest side of the bank. Thus, this research focused there. We conducted surveys mainly in February and March due to the vegetation and climate at that time of year. In addition, dead grasses are burned then, improving visibility. An air survey was also attempted using a drone (DJI Phantom 3 Pro), but it proved difficult to locate quarries unless they were large and highly visible. We recorded the location of quarries discovered during this survey using GPS, photographed them, and non-destructively measured the sandstone's magnetic susceptibility on site at up to 30 points (ZH instruments SM30, Brno, Czech Republic). Measuring magnetic susceptibility is easy and rapid (a few second per point), with high accuracy (1 $\times 10^{-6}$ SI units). Uchida et al. (1998) first succeeded in classifying the Angkor monument sandstone using magnetic susceptibility. Additionally, we measured step height at up to 20 points because the Angkor monument sandstone blocks thinned over time.

\section{Results}

\subsection{Distribution and Shape of the Quarries}

In this survey, we confirmed 89 sandstone quarries beyond the 56 previously identified (Uchida and Shimoda, 2013), bringing the total to 145 (Figure 1). Photographs of all of the quarries are presented in Appendix 1 (Figure A). In addition, the location of each quarry is shown in Figure 2 and Table 1.

Most quarries are concentrated in the east and north sides of the bank and distributed on the foothills' slopes (approximately 90 - $100 \mathrm{~m}$ asl) and tops (approximately $120-130 \mathrm{~m}$ asl). The sandstone quarries' distribution depicted in Figure 2 coincides with data obtained through airborne laser scanning (Evans, 2016). Although the planar spread is not always clear, many quarries are on the order of $10-30 \mathrm{~m}$. Quarries are generally less than $2 \mathrm{~m}$ high but occasionally reach $6 \mathrm{~m}$. Their traces are generally in the form of steps, but sometimes the quarries are found in flat areas as well. The step height is often $30-50 \mathrm{~cm}$, but occasionally exceeds $60 \mathrm{~cm}$; the average step height is $41 \mathrm{~cm}$. Oblique quarrying traces were observed on the quarries' stone surfaces, which may suggest the use of pickaxes (Figure 1(D)).

\subsection{Magnetic Susceptibility}

The average magnetic susceptibility in each quarry is $0.33 \times 10^{-3}$ SI units (quarry 
no. 43 ) at a minimum and $5.82 \times 10^{-3}$ SI units (quarry no. 70) at a maximum (Table 1). The total average value is $2.02 \times 10^{-3}$ SI units. The sandstone quarries with high magnetic susceptibilities are concentrated near the bank's eastern end and about $1 \mathrm{~km}$ north of the eastern end. In the latter case, the step height tends to be higher.
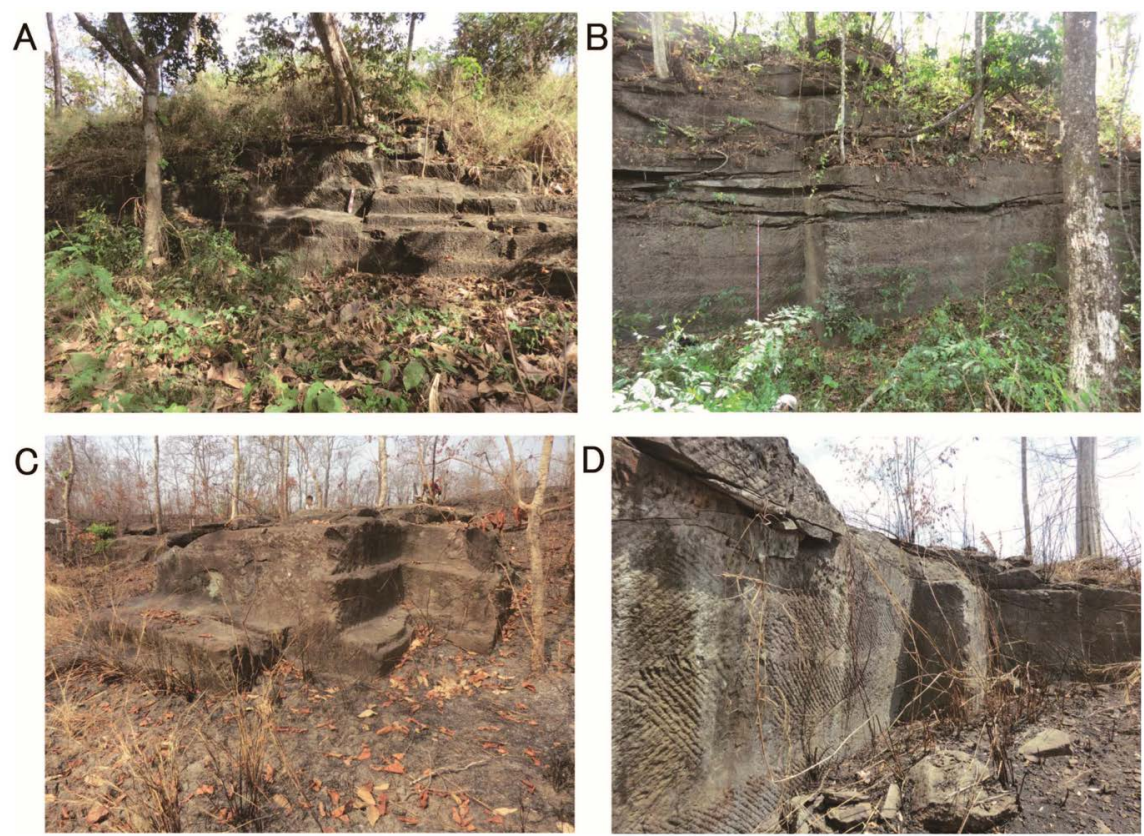

Figure 1. Photographs of representative sandstone quarries in Kulen Mountain's southeastern foothills. Photographs of all sandstone quarries are presented in Appendix 1 (Figure A). Quarries no. (A) 62, (B) 66, (C) 84, and (D) 123.

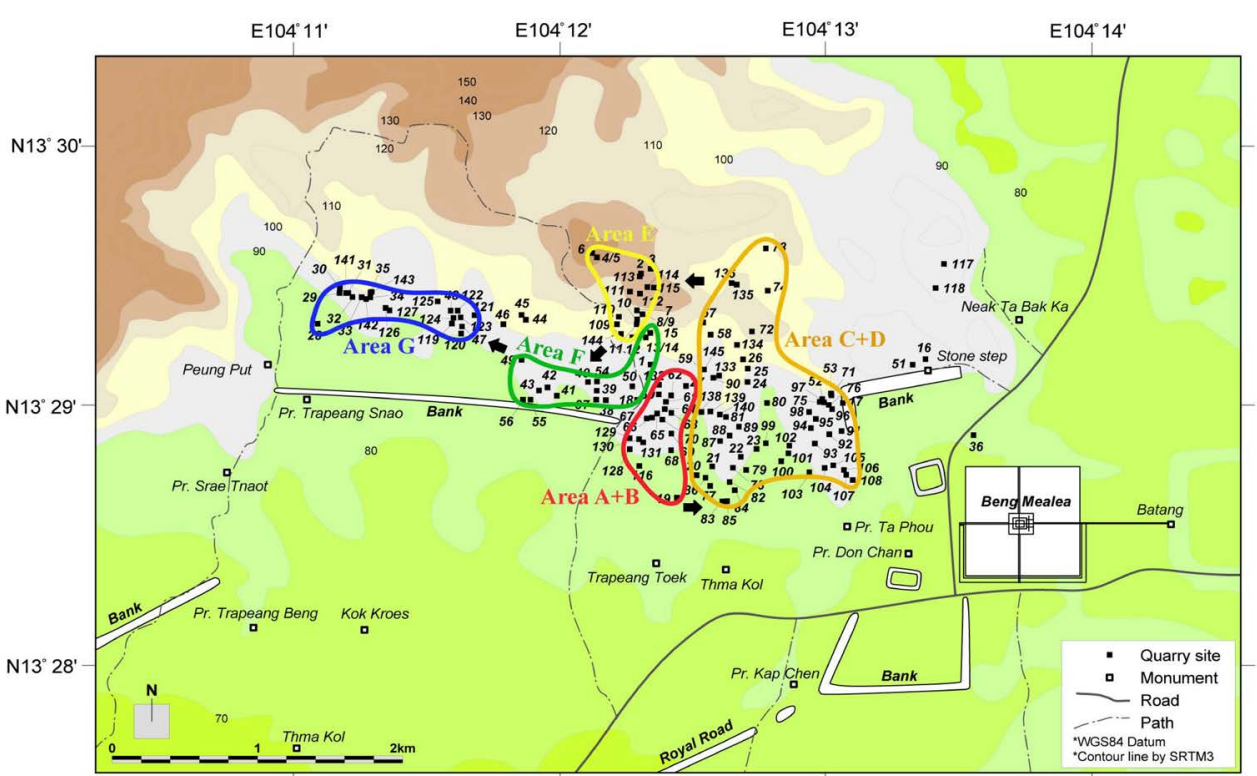

Figure 2. Distribution of sandstone quarries used during the Angkor period in Kulen Mountain's southeastern foothills. 
E. Uchida et al.

Table 1. Location, average magnetic susceptibilities, and average step heights of confirmed sandstone quarries.

\begin{tabular}{|c|c|c|c|c|c|c|c|c|c|}
\hline Quarry No. & Latitude & Longitude & av. S.H.** & av. M.S.* & Quarry No. & Latitude & Longitude & av. S.H. ${ }^{* *}$ & av. M.S.* \\
\hline 1 & $13^{\circ} 29^{\prime} 09.32^{\prime \prime} \mathrm{N}$ & $104^{\circ} 12^{\prime} 19.53^{\prime \prime} \mathrm{E}$ & 41.7 & 0.68 & 74 & $13^{\circ} 29^{\prime} 25.20^{\prime \prime} \mathrm{N}$ & $104^{\circ} 12^{\prime} 45.90^{\prime \prime} \mathrm{E}$ & 44.9 & 1.6 \\
\hline 2 & $13^{\circ} 29^{\prime} 29.46^{\prime \prime} \mathrm{N}$ & $104^{\circ} 12^{\prime} 18.80^{\prime \prime} \mathrm{E}$ & 65.5 & 1.28 & 75 & $13^{\circ} 29^{\prime} 00.50^{\prime \prime} \mathrm{N}$ & $104^{\circ} 12^{\prime} 57.60^{\prime \prime} \mathrm{E}$ & 46 & 0.33 \\
\hline 3 & $13^{\circ} 29^{\prime} 30.26^{\prime \prime N}$ & $104^{\circ} 12^{\prime} 19.56^{\prime \prime} \mathrm{E}$ & 57.3 & 2.70 & 76 & $13^{\circ} 28^{\prime} 59.70^{\prime \prime N}$ & $104^{\circ} 12^{\prime} 59.90^{\prime \prime} \mathrm{E}$ & 33.8 & 0.46 \\
\hline 4 & $13^{\circ} 29^{\prime} 33.54^{\prime \prime} \mathrm{N}$ & $104^{\circ} 12^{\prime} 08.89^{\prime \prime} \mathrm{E}$ & N/A & 2.67 & 77 & $13^{\circ} 28^{\prime} 41.40^{\prime \prime} \mathrm{N}$ & $104^{\circ} 12^{\prime} 34.90^{\prime \prime} \mathrm{E}$ & 43.9 & 2.80 \\
\hline 5 & $13^{\circ} 29^{\prime} 32.80^{\prime \prime} \mathrm{N}$ & $104^{\circ} 12^{\prime} 07.86^{\prime \prime} \mathrm{E}$ & 47.3 & 2.82 & 78 & $13^{\circ} 28^{\prime} 45.50^{\prime \prime} \mathrm{N}$ & $104^{\circ} 12^{\prime} 40.00^{\prime \prime} \mathrm{E}$ & 40.8 & 1.80 \\
\hline 6 & $13^{\circ} 29^{\prime} 33.93^{\prime \prime} \mathrm{N}$ & $104^{\circ} 12^{\prime} 07.24^{\prime \prime} \mathrm{E}$ & 56.4 & 4.53 & 79 & $13^{\circ} 28^{\prime} 45.20^{\prime \prime} \mathrm{N}$ & $104^{\circ} 12^{\prime} 43.00^{\prime \prime} \mathrm{E}$ & N/A & 2.05 \\
\hline 7 & $13^{\circ} 29^{\prime} 20.95^{\prime \prime} \mathrm{N}$ & $104^{\circ} 12^{\prime} 16.45^{\prime \prime} \mathrm{E}$ & 46.9 & 2.09 & 80 & $13^{\circ} 29^{\prime} 00.00^{\prime \prime} \mathrm{N}$ & $104^{\circ} 12^{\prime} 47.70^{\prime \prime} \mathrm{E}$ & N/A & 0.97 \\
\hline 8 & $13^{\circ} 29^{\prime} 20.10^{\prime \prime} \mathrm{N}$ & $104^{\circ} 12^{\prime} 18.05^{\prime \prime} \mathrm{E}$ & 47.5 & 3.31 & 81 & $13^{\circ} 28^{\prime} 56.80^{\prime \prime} \mathrm{N}$ & $104^{\circ} 12^{\prime} 38.50^{\prime \prime} \mathrm{E}$ & 40.1 & 1.62 \\
\hline 9 & $13^{\circ} 29^{\prime} 19.36^{\prime \prime} \mathrm{N}$ & $104^{\circ} 12^{\prime} 18.42^{\prime \prime} \mathrm{E}$ & 39.2 & 2.99 & 82 & $13^{\circ} 28^{\prime} 42.20^{\prime \prime} \mathrm{N}$ & $104^{\circ} 12^{\prime} 39.30^{\prime \prime} \mathrm{E}$ & 39.7 & 1.12 \\
\hline 10 & $13^{\circ} 29^{\prime} 18.58^{\prime \prime} \mathrm{N}$ & $104^{\circ} 12^{\prime} 17.06^{\prime \prime} \mathrm{E}$ & 43.4 & 3.57 & 83 & $13^{\circ} 28^{\prime} 37.90^{\prime \prime} \mathrm{N}$ & $104^{\circ} 12^{\prime} 38.60^{\prime \prime} \mathrm{E}$ & N/A & 1.49 \\
\hline 11 & $13^{\circ} 29^{\prime} 18.08^{\prime \prime} \mathrm{N}$ & $104^{\circ} 12^{\prime} 17.86^{\prime \prime} \mathrm{E}$ & 49.2 & 3.38 & 84 & $13^{\circ} 28^{\prime} 40.40^{\prime \prime} \mathrm{N}$ & $104^{\circ} 12^{\prime} 40.30^{\prime \prime} \mathrm{E}$ & 41.5 & 1.42 \\
\hline 12 & $13^{\circ} 29^{\prime} 15.40^{\prime \prime} \mathrm{N}$ & $104^{\circ} 12^{\prime} 16.76^{\prime \prime} \mathrm{E}$ & N/A & 3.50 & 85 & $13^{\circ} 28^{\prime} 38.10^{\prime \prime} \mathrm{N}$ & $104^{\circ} 12^{\prime} 37.50^{\prime \prime} \mathrm{E}$ & 37 & 1.54 \\
\hline 13 & $13^{\circ} 29^{\prime} 14.93^{\prime \prime} \mathrm{N}$ & $104^{\circ} 12^{\prime} 18.39^{\prime \prime} \mathrm{E}$ & 44.8 & 1.05 & 86 & $13^{\circ} 28^{\prime} 43.30^{\prime \prime} \mathrm{N}$ & $104^{\circ} 12^{\prime} 33.70^{\prime \prime} \mathrm{E}$ & 44.3 & 2.21 \\
\hline 14 & $13^{\circ} 29^{\prime} 15.25^{\prime \prime} \mathrm{N}$ & $104^{\circ} 12^{\prime} 19.39^{\prime \prime} \mathrm{E}$ & 41.5 & 1.98 & 87 & $13^{\circ} 28^{\prime} 51.50^{\prime \prime N}$ & $104^{\circ} 12^{\prime} 37.30^{\prime \prime} \mathrm{E}$ & 40.5 & 2.05 \\
\hline 15 & $13^{\circ} 29^{\prime} 14.48^{\prime \prime} \mathrm{N}$ & $104^{\circ} 12^{\prime} 18.34^{\prime \prime} \mathrm{E}$ & 55.3 & 1.15 & 88 & $13^{\circ} 28^{\prime} 52.70^{\prime \prime} \mathrm{N}$ & $104^{\circ} 12^{\prime} 39.50^{\prime \prime} \mathrm{E}$ & N/A & 1.51 \\
\hline 16 & $13^{\circ} 29^{\prime} 09.50^{\prime \prime} \mathrm{N}$ & $104^{\circ} 13^{\prime} 21.50^{\prime \prime} \mathrm{E}$ & N/A & 1.99 & 89 & $13^{\circ} 28^{\prime} 54.60^{\prime \prime} \mathrm{N}$ & $104^{\circ} 12^{\prime} 41.40^{\prime \prime} \mathrm{E}$ & 43.2 & 1.58 \\
\hline 17 & $13^{\circ} 29^{\prime} 00.30^{\prime \prime} \mathrm{N}$ & $104^{\circ} 13^{\prime} 04.50^{\prime \prime} \mathrm{E}$ & 53.3 & 2.46 & 90 & $13^{\circ} 29^{\prime} 05.40^{\prime \prime} \mathrm{N}$ & $104^{\circ} 12^{\prime} 35.90^{\prime \prime} \mathrm{E}$ & N/A & 0.91 \\
\hline 18 & $13^{\circ} 29^{\prime} 01.20^{\prime \prime} \mathrm{N}$ & $104^{\circ} 12^{\prime} 17.40^{\prime \prime} \mathrm{E}$ & 47.8 & 0.97 & 91 & $13^{\circ} 28^{\prime} 53.60^{\prime \prime} \mathrm{N}$ & $104^{\circ} 13^{\prime} 04.20^{\prime \prime} \mathrm{E}$ & 44.3 & 1.52 \\
\hline 19 & $13^{\circ} 28^{\prime} 39.00^{\prime \prime} \mathrm{N}$ & $104^{\circ} 12^{\prime} 25.75^{\prime \prime} \mathrm{E}$ & 44.4 & 2.49 & 92 & $13^{\circ} 28^{\prime} 53.00^{\prime \prime} \mathrm{N}$ & $104^{\circ} 13^{\prime} 01.40^{\prime \prime} \mathrm{E}$ & 46.5 & 1.82 \\
\hline 20 & $13^{\circ} 28^{\prime} 43.61^{\prime \prime N}$ & $104^{\circ} 12^{\prime} 31.80^{\prime \prime E}$ & 42.5 & 1.61 & 93 & $13^{\circ} 28^{\prime} 51.00^{\prime \prime} \mathrm{N}$ & $104^{\circ} 12^{\prime} 58.30^{\prime \prime} \mathrm{E}$ & 44.5 & 2.32 \\
\hline 21 & $13^{\circ} 28^{\prime} 46.14^{\prime \prime} \mathrm{N}$ & $104^{\circ} 12^{\prime} 33.44^{\prime \prime} \mathrm{E}$ & 41.5 & 1.92 & 94 & $13^{\circ} 28^{\prime} 54.40^{\prime \prime} \mathrm{N}$ & $104^{\circ} 12^{\prime} 57.50^{\prime \prime E}$ & 43.2 & 3.26 \\
\hline 22 & $13^{\circ} 28^{\prime} 48.03^{\prime \prime N}$ & $104^{\circ} 12^{\prime} 41.82^{\prime \prime} \mathrm{E}$ & 53.1 & 2.14 & 95 & $13^{\circ} 28^{\prime} 56.40^{\prime \prime} \mathrm{N}$ & $104^{\circ} 12^{\prime} 58.50^{\prime \prime} \mathrm{E}$ & 47 & 1.53 \\
\hline 23 & $13^{\circ} 28^{\prime} 50.19^{\prime \prime} \mathrm{N}$ & $104^{\circ} 12^{\prime} 43.86^{\prime \prime} \mathrm{E}$ & 34.8 & 2.62 & 96 & $13^{\circ} 28^{\prime} 58.60^{\prime \prime} \mathrm{N}$ & $104^{\circ} 13^{\prime} 02.10^{\prime \prime} \mathrm{E}$ & 44.4 & 2.59 \\
\hline 24 & $13^{\circ} 29^{\prime} 04.63^{\prime \prime} \mathrm{N}$ & $104^{\circ} 12^{\prime} 42.55^{\prime \prime} \mathrm{E}$ & 43.3 & 1.90 & 97 & $13^{\circ} 29^{\prime} 00.10^{\prime \prime} \mathrm{N}$ & $104^{\circ} 13^{\prime} 00.40^{\prime \prime} \mathrm{E}$ & 42.7 & 1.66 \\
\hline 25 & $13^{\circ} 29^{\prime} 07.86^{\prime \prime} \mathrm{N}$ & $104^{\circ} 12^{\prime} 42.55^{\prime \prime} \mathrm{E}$ & 43.1 & 2.21 & 98 & $13^{\circ} 28^{\prime} 57.90^{\prime \prime} \mathrm{N}$ & $104^{\circ} 12^{\prime} 57.10^{\prime \prime} \mathrm{E}$ & 44.5 & 0.86 \\
\hline 26 & $13^{\circ} 29^{\prime} 09.35^{\prime \prime} \mathrm{N}$ & $104^{\circ} 12^{\prime} 41.04^{\prime \prime} \mathrm{E}$ & 37.9 & 4.26 & 99 & $13^{\circ} 28^{\prime} 51.00^{\prime \prime} \mathrm{N}$ & $104^{\circ} 12^{\prime} 47.40^{\prime \prime} \mathrm{E}$ & 45.4 & 0.64 \\
\hline 27 & $13^{\circ} 29^{\prime} 03.79^{\prime \prime} \mathrm{N}$ & $104^{\circ} 12^{\prime} 27.66^{\prime \prime} \mathrm{E}$ & 63.4 & 3.64 & 100 & $13^{\circ} 28^{\prime} 46.90^{\prime \prime} \mathrm{N}$ & $104^{\circ} 12^{\prime} 50.70^{\prime \prime} \mathrm{E}$ & 44.7 & 3.97 \\
\hline 28 & $13^{\circ} 29^{\prime} 17.83^{\prime \prime} \mathrm{N}$ & $104^{\circ} 11^{\prime} 05.23^{\prime \prime} \mathrm{E}$ & 32.8 & 1.70 & 101 & $13^{\circ} 28^{\prime} 48.70^{\prime \prime} \mathrm{N}$ & $104^{\circ} 12^{\prime} 52.50^{\prime \prime} \mathrm{E}$ & 50.8 & 1.97 \\
\hline 29 & $13^{\circ} 29^{\prime} 25.21^{\prime \prime} \mathrm{N}$ & $104^{\circ} 11^{\prime} 09.24^{\prime \prime E}$ & 31.8 & 2.08 & 102 & $13^{\circ} 28^{\prime} 50.50^{\prime \prime} \mathrm{N}$ & $104^{\circ} 12^{\prime} 52.70^{\prime \prime} \mathrm{E}$ & 38.3 & 1.7 \\
\hline 30 & $13^{\circ} 29^{\prime} 26.14^{\prime \prime} \mathrm{N}$ & $104^{\circ} 11^{\prime} 09.68^{\prime \prime} \mathrm{E}$ & 31.3 & 2.01 & 103 & $13^{\circ} 28^{\prime} 44.60^{\prime \prime} \mathrm{N}$ & $104^{\circ} 12^{\prime} 57.10^{\prime \prime} \mathrm{E}$ & N/A & 0.91 \\
\hline 31 & $13^{\circ} 29^{\prime} 25.50^{\prime \prime} \mathrm{N}$ & $104^{\circ} 11^{\prime} 11.94^{\prime \prime E}$ & 31.9 & 2.00 & 104 & $13^{\circ} 28^{\prime} 45.50^{\prime \prime} \mathrm{N}$ & $104^{\circ} 13^{\prime} 00.50^{\prime \prime} \mathrm{E}$ & 44.3 & 2.52 \\
\hline 32 & $13^{\circ} 29^{\prime} 24.04^{\prime \prime} \mathrm{N}$ & $104^{\circ} 11^{\prime} 13.38^{\prime \prime E}$ & 29.3 & 1.76 & 105 & $13^{\circ} 28^{\prime} 46.10^{\prime \prime} \mathrm{N}$ & $104^{\circ} 13^{\prime} 02.40^{\prime \prime} \mathrm{E}$ & N/A & 1.87 \\
\hline 33 & $13^{\circ} 29^{\prime} 23.55^{\prime \prime} \mathrm{N}$ & $104^{\circ} 11^{\prime} 14.77^{\prime \prime E}$ & 34.1 & 1.63 & 106 & $13^{\circ} 28^{\prime} 45.10^{\prime \prime} \mathrm{N}$ & $104^{\circ} 13^{\prime} 04.70^{\prime \prime} \mathrm{E}$ & N/A & 0.54 \\
\hline 34 & $13^{\circ} 29^{\prime} 23.83^{\prime \prime} \mathrm{N}$ & $104^{\circ} 11^{\prime} 16.71^{\prime \prime E}$ & 30.3 & 1.68 & 107 & $13^{\circ} 28^{\prime} 44.30^{\prime \prime} \mathrm{N}$ & $104^{\circ} 13^{\prime} 05.40^{\prime \prime E}$ & 42.4 & 0.97 \\
\hline 35 & $13^{\circ} 29^{\prime} 24.55^{\prime \prime} \mathrm{N}$ & $104^{\circ} 11^{\prime} 16.75^{\prime \prime E}$ & 31.3 & 2.05 & 108 & $13^{\circ} 28^{\prime} 42.80^{\prime \prime} \mathrm{N}$ & $104^{\circ} 13^{\prime} 06.80^{\prime \prime} \mathrm{E}$ & N/A & 0.38 \\
\hline 36 & $13^{\circ} 28^{\prime} 52.70^{\prime \prime} \mathrm{N}$ & $104^{\circ} 13^{\prime} 33.00^{\prime \prime} \mathrm{E}$ & 33.2 & 0.77 & 109 & $13^{\circ} 29^{\prime} 17.50^{\prime \prime} \mathrm{N}$ & $104^{\circ} 12^{\prime} 14.30^{\prime \prime} \mathrm{E}$ & 39 & 2.23 \\
\hline
\end{tabular}




\section{Continued}

\begin{tabular}{|c|c|c|c|c|c|c|c|c|c|}
\hline 37 & $13^{\circ} 29^{\prime} 00.63^{\prime \prime} \mathrm{N}$ & $104^{\circ} 12^{\prime} 07.77^{\prime \prime} \mathrm{E}$ & 31.2 & 1.44 & 110 & $13^{\circ} 29^{\prime} 19.00^{\prime \prime} \mathrm{N}$ & $104^{\circ} 12^{\prime} 14.80^{\prime \prime E}$ & 39 & 2.13 \\
\hline 38 & $13^{\circ} 29^{\prime} 01.72 " \mathrm{~N}$ & $104^{\circ} 12^{\prime} 10.33^{\prime \prime} \mathrm{E}$ & 40.9 & 1.43 & 111 & $13^{\circ} 29^{\prime} 24.40^{\prime \prime} \mathrm{N}$ & $104^{\circ} 12^{\prime} 17.50^{\prime \prime} \mathrm{E}$ & 46.2 & 2.97 \\
\hline 39 & $13^{\circ} 29^{\prime} 02.77^{\prime \prime} \mathrm{N}$ & $104^{\circ} 12^{\prime} 08.18^{\prime \prime} \mathrm{E}$ & 27.3 & 0.75 & 112 & $13^{\circ} 29^{\prime} 24.00^{\prime \prime} \mathrm{N}$ & $104^{\circ} 12^{\prime} 19.70^{\prime \prime} \mathrm{E}$ & 35 & 1.51 \\
\hline 40 & $13^{\circ} 29^{\prime} 04.57^{\prime \prime} \mathrm{N}$ & $104^{\circ} 12^{\prime} 06.35^{\prime \prime} \mathrm{E}$ & N/A & 0.49 & 113 & $13^{\circ} 29^{\prime} 27.90^{\prime \prime} \mathrm{N}$ & $104^{\circ} 12^{\prime} 19.70^{\prime \prime E}$ & 45.3 & 1.73 \\
\hline 41 & $13^{\circ} 29^{\prime} 02.44^{\prime \prime} \mathrm{N}$ & $104^{\circ} 11^{\prime} 58.62^{\prime \prime} \mathrm{E}$ & 42.2 & 0.80 & 114 & $13^{\circ} 29^{\prime} 25.50^{\prime \prime} \mathrm{N}$ & $104^{\circ} 12^{\prime} 21.40^{\prime \prime} \mathrm{E}$ & 40 & 1.05 \\
\hline 42 & $13^{\circ} 29^{\prime} 03.49^{\prime \prime} \mathrm{N}$ & $104^{\circ} 11^{\prime} 57.54^{\prime \prime} \mathrm{E}$ & 28.6 & 1.09 & 115 & $13^{\circ} 29^{\prime} 25.40^{\prime \prime} \mathrm{N}$ & $104^{\circ} 12^{\prime} 22.70^{\prime \prime} \mathrm{E}$ & 43.3 & 1.92 \\
\hline 43 & $13^{\circ} 29^{\prime} 02.70^{\prime \prime} \mathrm{N}$ & $104^{\circ} 11^{\prime} 55.06^{\prime \prime} \mathrm{E}$ & 36.3 & 0.33 & 116 & $13^{\circ} 28^{\prime} 45.9^{\prime \prime N}$ & $104^{\circ} 12^{\prime} 18.2^{\prime \prime} \mathrm{E}$ & 40.5 & 1.54 \\
\hline 44 & $13^{\circ} 29^{\prime} 19.20^{\prime \prime} \mathrm{N}$ & $104^{\circ} 11^{\prime} 52.17^{\prime \prime} \mathrm{E}$ & 36.2 & 0.77 & 117 & $13^{\circ} 29^{\prime} 31.9^{\prime \prime} \mathrm{N}$ & $104^{\circ} 13^{\prime} 27.8^{\prime \prime} \mathrm{E}$ & N/A & 1.52 \\
\hline 45 & $13^{\circ} 29^{\prime} 20.17^{\prime \prime} \mathrm{N}$ & $104^{\circ} 11^{\prime} 51.42^{\prime \prime} \mathrm{E}$ & 32.8 & 0.99 & 118 & $13^{\circ} 29^{\prime} 26.5^{\prime \prime} \mathrm{N}$ & $104^{\circ} 13^{\prime} 25.9^{\prime \prime} \mathrm{E}$ & N/A & 1.09 \\
\hline 46 & $13^{\circ} 29^{\prime} 18.17^{\prime \prime} \mathrm{N}$ & $104^{\circ} 11^{\prime} 46.78^{\prime \prime} \mathrm{E}$ & $\mathrm{N} / \mathrm{A}$ & 0.54 & 119 & $13^{\circ} 29^{\prime} 18.4^{\prime \prime} \mathrm{N}$ & $104^{\circ} 11^{\prime} 35.2^{\prime \prime E}$ & 45.7 & 3.15 \\
\hline 47 & $13^{\circ} 29^{\prime} 17.14^{\prime \prime} \mathrm{N}$ & $104^{\circ} 11^{\prime} 37.99^{\prime \prime} \mathrm{E}$ & 46.1 & 2.09 & 120 & $13^{\circ} 29^{\prime} 16.5^{\prime \prime} \mathrm{N}$ & $104^{\circ} 11^{\prime} 37.6^{\prime \prime} \mathrm{E}$ & 53.3 & 2.53 \\
\hline 48 & $13^{\circ} 29^{\prime} 20.35^{\prime \prime} \mathrm{N}$ & $104^{\circ} 11^{\prime} 35.15^{\prime \prime} \mathrm{E}$ & 31.5 & 1.79 & 121 & $13^{\circ} 29^{\prime} 20.3^{\prime \prime} \mathrm{N}$ & $104^{\circ} 11^{\prime} 40.4^{\prime \prime} \mathrm{E}$ & 36.2 & 2.05 \\
\hline 49 & $13^{\circ} 29^{\prime} 09.82^{\prime \prime} \mathrm{N}$ & $104^{\circ} 11^{\prime} 50.83^{\prime \prime} \mathrm{E}$ & $\mathrm{N} / \mathrm{A}$ & 0.88 & 122 & $13^{\circ} 29^{\prime} 21.3^{\prime \prime} \mathrm{N}$ & $104^{\circ} 11^{\prime} 36.7^{\prime \prime} \mathrm{E}$ & 42 & 2.81 \\
\hline 50 & $13^{\circ} 29^{\prime} 03.63^{\prime \prime} \mathrm{N}$ & $104^{\circ} 12^{\prime} 16.13^{\prime \prime} \mathrm{E}$ & 43.3 & 0.71 & 123 & $13^{\circ} 29^{\prime} 19.7^{\prime \prime} \mathrm{N}$ & $104^{\circ} 11^{\prime} 37.3^{\prime \prime} \mathrm{E}$ & 49.8 & 2.71 \\
\hline 51 & $13^{\circ} 29^{\prime} 09.20^{\prime \prime} \mathrm{N}$ & $104^{\circ} 13^{\prime} 18.50^{\prime \prime} \mathrm{E}$ & $\mathrm{N} / \mathrm{A}$ & - & 124 & $13^{\circ} 29^{\prime} 19.6^{\prime \prime} \mathrm{N}$ & $104^{\circ} 11^{\prime} 35.6^{\prime \prime E}$ & 39.3 & 1.41 \\
\hline 52 & $13^{\circ} 29^{\prime} 02.50^{\prime \prime} \mathrm{N}$ & $104^{\circ} 12^{\prime} 57.90^{\prime \prime} \mathrm{E}$ & 67.0 & 1.9 & 125 & $13^{\circ} 29^{\prime} 23.5^{\prime \prime} \mathrm{N}$ & $104^{\circ} 11^{\prime} 32.0^{\prime \prime} \mathrm{E}$ & 44 & 2.12 \\
\hline 53 & $13^{\circ} 29^{\prime} 05.20^{\prime \prime} \mathrm{N}$ & $104^{\circ} 12^{\prime} 59.90^{\prime \prime} \mathrm{E}$ & $\mathrm{N} / \mathrm{A}$ & - & 126 & $13^{\circ} 29^{\prime} 21.4^{\prime \prime} \mathrm{N}$ & $104^{\circ} 11^{\prime} 21.2^{\prime \prime} \mathrm{E}$ & 44 & 1.15 \\
\hline 54 & $13^{\circ} 29^{\prime} 04.71 " \mathrm{~N}$ & $104^{\circ} 12^{\prime} 06.97^{\prime \prime} \mathrm{E}$ & 35.5 & - & 127 & $13^{\circ} 29^{\prime} 21.9^{\prime \prime} \mathrm{N}$ & $104^{\circ} 11^{\prime} 20.2^{\prime \prime} \mathrm{E}$ & 40.3 & 1.48 \\
\hline 55 & $13^{\circ} 29^{\prime} 00.99^{\prime \prime} \mathrm{N}$ & $104^{\circ} 11^{\prime} 54.57^{\prime \prime} \mathrm{E}$ & N/A & - & 128 & $13^{\circ} 28^{\prime} 49.8^{\prime \prime} \mathrm{N}$ & $104^{\circ} 12^{\prime} 16.0^{\prime \prime} \mathrm{E}$ & 38.5 & 3.35 \\
\hline 57 & $13^{\circ} 29^{\prime} 18.10^{\prime \prime} \mathrm{N}$ & $104^{\circ} 12^{\prime} 31.60^{\prime \prime E}$ & 46.7 & 2.29 & 130 & $13^{\circ} 28^{\prime} 52.0^{\prime \prime} \mathrm{N}$ & $104^{\circ} 12^{\prime} 18.2^{\prime \prime} \mathrm{E}$ & 38.3 & 3.72 \\
\hline 58 & $13^{\circ} 29^{\prime} 15.30^{\prime \prime} \mathrm{N}$ & $104^{\circ} 12^{\prime} 33.20^{\prime \prime} \mathrm{E}$ & 41.7 & 3.12 & 131 & $13^{\circ} 28^{\prime} 51.3^{\prime \prime} \mathrm{N}$ & $104^{\circ} 12^{\prime} 19.0^{\prime \prime} \mathrm{E}$ & 39.5 & 4.16 \\
\hline 59 & $13^{\circ} 29^{\prime} 07.60^{\prime \prime} \mathrm{N}$ & $104^{\circ} 12^{\prime} 31.10^{\prime \prime} \mathrm{E}$ & 47.2 & 0.61 & 132 & $13^{\circ} 29^{\prime} 4.4^{\prime \prime} \mathrm{N}$ & $104^{\circ} 12^{\prime} 22.6^{\prime \prime E}$ & 31.3 & 2.99 \\
\hline 60 & $13^{\circ} 29^{\prime} 02.00^{\prime \prime} \mathrm{N}$ & $104^{\circ} 12^{\prime} 21.70^{\prime \prime} \mathrm{E}$ & 54.3 & 2.91 & 133 & $13^{\circ} 29^{\prime} 6.5^{\prime \prime} \mathrm{N}$ & $104^{\circ} 12^{\prime} 36.4^{\prime \prime} \mathrm{E}$ & 41.1 & 0.59 \\
\hline 61 & $13^{\circ} 29^{\prime} 00.40^{\prime \prime} \mathrm{N}$ & $104^{\circ} 12^{\prime} 23.30^{\prime \prime} \mathrm{E}$ & 30.4 & 2.81 & 134 & $13^{\circ} 29^{\prime} 13.5^{\prime \prime} \mathrm{N}$ & $104^{\circ} 12^{\prime} 40.5^{\prime \prime} \mathrm{E}$ & 43.4 & 2.23 \\
\hline 62 & $13^{\circ} 29^{\prime} 01.70^{\prime \prime} \mathrm{N}$ & $104^{\circ} 12^{\prime} 24.50^{\prime \prime} \mathrm{E}$ & 40.4 & 3.61 & 135 & $13^{\circ} 29^{\prime} 27.2^{\prime \prime} \mathrm{N}$ & $104^{\circ} 12^{\prime} 40.4^{\prime \prime} \mathrm{E}$ & 41.7 & 2.72 \\
\hline 63 & $13^{\circ} 28^{\prime} 57.90^{\prime \prime} \mathrm{N}$ & $104^{\circ} 12^{\prime} 24.50^{\prime \prime} \mathrm{E}$ & 58.3 & 1.73 & 136 & $13^{\circ} 29^{\prime} 27.6^{\prime \prime} \mathrm{N}$ & $104^{\circ} 12^{\prime} 39.3^{\prime \prime E}$ & 44 & 1.70 \\
\hline 64 & $13^{\circ} 28^{\prime} 58.60^{\prime \prime} \mathrm{N}$ & $104^{\circ} 12^{\prime} 23.10^{\prime \prime E}$ & 29.8 & 1.25 & 137 & $13^{\circ} 29^{\prime} 4.2^{\prime \prime} \mathrm{N}$ & $104^{\circ} 12^{\prime} 29.2^{\prime \prime} \mathrm{E}$ & 45.4 & 3.03 \\
\hline 65 & $13^{\circ} 28^{\prime} 57.80^{\prime \prime} \mathrm{N}$ & $104^{\circ} 12^{\prime} 21.30^{\prime \prime} \mathrm{E}$ & 31.5 & 1.96 & 138 & $13^{\circ} 28^{\prime} 58.2^{\prime \prime} \mathrm{N}$ & $104^{\circ} 12^{\prime} 32.5^{\prime \prime} \mathrm{E}$ & 42.2 & 1.74 \\
\hline 66 & $13^{\circ} 28^{\prime} 56.90^{\prime \prime} \mathrm{N}$ & $104^{\circ} 12^{\prime} 20.20^{\prime \prime} \mathrm{E}$ & 34.5 & 1.56 & 139 & $13^{\circ} 28^{\prime} 58.4^{\prime \prime} \mathrm{N}$ & $104^{\circ} 12^{\prime} 34.5^{\prime \prime} \mathrm{E}$ & 52 & 1.92 \\
\hline 67 & $13^{\circ} 28^{\prime} 56.70 " \mathrm{~N}$ & $104^{\circ} 12^{\prime} 19.10^{\prime \prime} \mathrm{E}$ & 37.9 & 2.51 & 140 & $13^{\circ} 28^{\prime} 57.7^{\prime \prime} \mathrm{N}$ & $104^{\circ} 12^{\prime} 35.6^{\prime \prime E}$ & 44.7 & 1.33 \\
\hline 68 & $13^{\circ} 28^{\prime} 49.50^{\prime \prime} \mathrm{N}$ & $104^{\circ} 12^{\prime} 24.40^{\prime \prime} \mathrm{E}$ & 51.4 & 2.5 & 141 & $13^{\circ} 29^{\prime} 25.0^{\prime \prime} \mathrm{N}$ & $104^{\circ} 11^{\prime} 11.2^{\prime \prime} \mathrm{E}$ & 32.6 & 1.97 \\
\hline 69 & $13^{\circ} 28^{\prime} 53.30^{\prime \prime} \mathrm{N}$ & $104^{\circ} 12^{\prime} 24.60^{\prime \prime} \mathrm{E}$ & 41.0 & 4.13 & 142 & $13^{\circ} 29^{\prime} 23.6^{\prime \prime} \mathrm{N}$ & $104^{\circ} 11^{\prime} 15.8^{\prime \prime} \mathrm{E}$ & 31.4 & 1.85 \\
\hline 70 & $13^{\circ} 28^{\prime} 56.40^{\prime \prime} \mathrm{N}$ & $104^{\circ} 12^{\prime} 22.50^{\prime \prime} \mathrm{E}$ & 37.7 & 5.82 & 143 & $13^{\circ} 29^{\prime} 24.8^{\prime \prime} \mathrm{N}$ & $104^{\circ} 11^{\prime} 17.0 " \mathrm{E}$ & 31.8 & 1.68 \\
\hline 71 & $13^{\circ} 29^{\prime} 01.70 " \mathrm{~N}$ & $104^{\circ} 13^{\prime} 00.20^{\prime \prime} \mathrm{E}$ & $\mathrm{N} / \mathrm{A}$ & 0.54 & 144 & $13^{\circ} 29^{\prime} 15.8^{\prime \prime} \mathrm{N}$ & $104^{\circ} 12^{\prime} 13.3^{\prime \prime} \mathrm{E}$ & 45.9 & 1.32 \\
\hline 72 & $13^{\circ} 29^{\prime} 16.10^{\prime \prime} \mathrm{N}$ & $104^{\circ} 12^{\prime} 42.50^{\prime \prime} \mathrm{E}$ & $\mathrm{N} / \mathrm{A}$ & 1.71 & 145 & $13^{\circ} 29^{\prime} 07.7^{\prime \prime} \mathrm{N}$ & $104^{\circ} 12^{\prime} 31.9^{\prime \prime} \mathrm{E}$ & 45.0 & 0.88 \\
\hline 73 & $13^{\circ} 29^{\prime} 34.60^{\prime \prime} \mathrm{N}$ & $104^{\circ} 12^{\prime} 45.60^{\prime \prime} \mathrm{E}$ & $\mathrm{N} / \mathrm{A}$ & 1.23 & & & & & \\
\hline
\end{tabular}

* Average step height $(\mathrm{cm}),{ }^{\star *}$ average magnetic susceptibility $\left(\times 10^{-3}\right.$ SI unit). 


\section{Discussion}

Uchida et al. (2003, 2007) measured the magnetic susceptibility of Angkor's gray-yellowish brown sandstone and classified the temple construction into 13 phases (Phases I to VIIIb) (Figure 3(A), Figure 3(B)). Judging from the frequency histogram of the magnetic susceptibility of gray-yellowish brown sandstone at each phase, they inferred that there were seven quarrying areas (Areas A to G) of gray-yellowish brown sandstone in the Angkor period (Figure 3(C)). Area A's sandstone has a relatively low magnetic susceptibility, with the average ranging from 1.1 to $2.3 \times 10^{-3} \mathrm{SI}$ units. Area B's sandstone has a very wide range of magnetic susceptibility ( 0.9 to $9.1 \times 10^{-3} \mathrm{SI}$ units), and the magnetic susceptibility tends to be high at the early stage and low later. Area C's magnetic susceptibility is somewhat high at 2.3 to $3.0 \times 10^{-3}$ SI units. Area D's magnetic susceptibility has a similar range to that of Area A. The magnetic susceptibility of Area E's sandstone is high (2.8 to $4.3 \times 10^{-3}$ SI units). Area F's sandstone's magnetic susceptibility is the lowest ( 0.7 to $1.4 \times 10^{-3} \mathrm{SI}$ units). Area G's sandstone's magnetic susceptibility is somewhat high at 1.9 to $3.1 \times 10^{-3} \mathrm{SI}$ units. The step height is comparatively low in Areas F and G.

According to Uchida et al. (2005), the stone blocks' cross sections, including laterite blocks from the Preah Ko period to the Baphuon period (the late $9^{\text {th }}$ century to middle $11^{\text {th }}$ century), are nearly square, and the side length is about 45 $\mathrm{cm}$, excepting some buildings constructed in the Preah Ko and Bakheng periods (the late $9^{\text {th }}$ century to early $10^{\text {th }}$ century). In the case of the Angkor Wat period (the late $11^{\text {th }}$ century to middle $12^{\text {th }}$ century), some stone blocks have a square cross section, but many are rectangular. Their widths are approximately $45 \mathrm{~cm}$ but tend to gradually thin. Larger stones are used exceptionally in the Angkor Wat and Wat Athvea temples.

Combining the quarry distribution map (Figure 2) and sandstone blocks' magnetic susceptibility and step height reveal that the quarries on the north side of the eastern half of the bank averaged a magnetic susceptibility as low as $0.96 \times$ $10^{-3} \mathrm{SI}$ units and have a slightly low step height $(39.4 \mathrm{~cm})$. These quarries' characteristics coincide with those in Area F of Phase VII (average magnetic susceptibility: $1.07 \times 10^{-3} \mathrm{SI}$ units); the quarries are inferred to have been used in the middle to later Bayon period (the late $12^{\text {th }}$ century to early $13^{\text {th }}$ century). The average magnetic susceptibility of the sandstone quarries distributed on the north of the western half of the bank is higher $\left(2.05 \times 10^{-3} \mathrm{SI}\right.$ units $)$ than on the north of the eastern half of the bank, and the step height is low $(37.3 \mathrm{~cm})$. It is thus speculated that the sandstone quarries on the north of the western half of the bank correspond to Area G (average magnetic susceptibility: $2.28 \times 10^{-3} \mathrm{SI}$ units), which dates to the end of the Bayon period through the post-Bayon period (the $13^{\text {th }}$ century).

Many sandstone quarries with high magnetic susceptibilities $\left(2.58 \times 10^{-3} \mathrm{SI}\right.$ units in average) occur about $1 \mathrm{~km}$ north of the eastern end of the bank and have high steps (average height: $45.7 \mathrm{~cm}$ ). It is thus deduced that these quarries cor- 


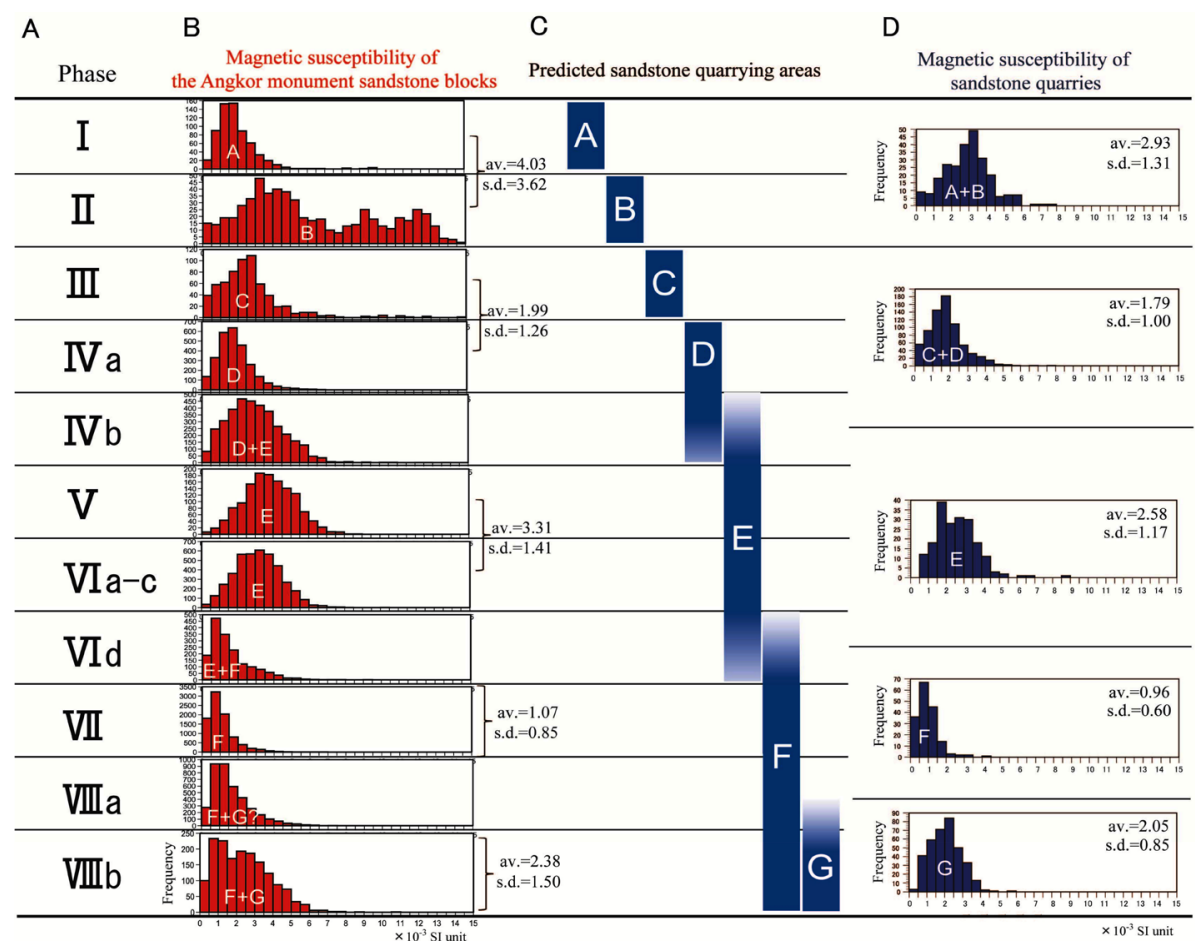

Figure 3. Frequency histograms of magnetic susceptibilities of sandstone in the quarrying Areas A + B, C + D, E, F, and G (Figure 2). (A) Construction phases based on the blocks' magnetic susceptibilities; (B) frequency histograms of sandstone's magnetic susceptibilities by construction phase, (C) predicted sandstone quarrying areas (Uchida et al., 2007); and (D) frequency histograms of sandstone in the deduced quarrying Areas A + B to G, which seem to agree with those for sandstone blocks used during each phase.

respond to Area E (average magnetic susceptibility: $3.31 \times 10^{-3}$ SI units) from the Angkor Wat period through the early Bayon period (the late $11^{\text {th }}$ century to late $12^{\text {th }}$ century) (Phases V to VIc).

Areas A to D cannot be clearly classified. Area A + B (Figure 2) contains sandstones with low to high magnetic susceptibility ( 0.52 to $5.82 \times 10^{-3}$ SI units, averaging $2.93 \times 10^{-3} \mathrm{SI}$ units), and the step height varies greatly from 29.8 to $63.4 \mathrm{~cm}$ (averaging $41.4 \mathrm{~cm}$ ). Although Areas A and B cannot be distinctly classified, the features of both Areas A and B appear in Area A + B (average magnetic susceptibility: $4.03 \times 10^{-3} \mathrm{SI}$ units). In Area $\mathrm{C}+\mathrm{D}$, the variation is smaller than Area A + B's and the magnetic susceptibility ranges from 0.33 to $4.26 \times 10^{-3}$ SI units (averaging $1.79 \times 10^{-3} \mathrm{SI}$ units). Furthermore, because the step height is close to the characteristic step height of the transition period through the Baphuon period (the early $10^{\text {th }}$ century to middle $11^{\text {th }}$ century) $(34.8$ to $67.0 \mathrm{~cm}$, averaging $45.7 \mathrm{~cm}$ ), Area C + D corresponds to Areas C and D (average magnetic susceptibility: $1.99 \times 10^{-3}$ SI units).

Compared to the magnetic susceptibility of the sandstone blocks used in the temples, the magnetic susceptibility of sandstone in the quarrying sites tends to below. This is probably due to the deterioration of sandstone surface from plant growth and the uneven surface of the sandstone in the quarrying sites. 
Figure 3(D) is a frequency histogram of magnetic susceptibilities in inferred quarrying Areas A to G. Area A + B has less sandstone with a magnetic susceptibility of $6 \times 10^{-3} \mathrm{SI}$ units or more when compared with the frequency histogram by Uchida et al. (2007), and there is very little sandstone with a magnetic susceptibility above $6 \times 10^{-3}$ SI units in other areas. The other areas (Areas $\mathrm{C}$ to $\mathrm{G}$ ) display a trend similar to that obtained by Uchida et al. (2007). Assuming that the estimated quarrying period is correct, the quarrying of sandstone blocks in the Angkor period began near the eastern end of the bank and then moved eastward. In the Angkor Wat period (the late $11^{\text {th }}$ century to middle $12^{\text {th }}$ century), the quarrying moved to the north side of the eastern end of the bank. In the Bayon period, quarrying shifted from the north side of the eastern half of the bank to the north side of the western half of the bank. It is therefore inferred that the quarrying site moved in an overall counterclockwise pattern during the Angkor period. Although there was no difference in sandstone chemical composition among the Angkor temples' blocks, changes in magnetic susceptibility and size over time played an important role in identifying quarries' usage period. Additionally, they clarified the movement of quarrying areas over time. These methods may be applicable to other Khmer monuments.

No evidence of artificial destruction has been found in the quarries investigated so far. Because quarries are also important Angkor period heritage sites, they should be designated as conservation areas for their protection. Many countries are involved in these monuments' restoration. Sandstone blocks from a site near ancient quarry no. 16 are used for restoration. It is desirable that the APSARA National Authority, which manages the archaeological sites in the Angkor area, protect the ancient quarries from destruction.

\section{Conclusion}

It has long been known that gray-yellowish brown sandstone quarries, which were used for the construction of the Angkor monuments, are located on the southeastern foothills of Kulen Mountain (Garnier, 1873; Delaporte, 1880; Delvert, 1963; Boulbet, 1979). Recently sandstone quarries were investigated by Carò and Im (2012) and Uchida and Shimoda (2013). Uchida and Shimoda (2013) tried to identify the quarrying period of the discovered sandstone quarries. They concluded that quarries used in the early Angkor period have not been discovered. Therefore, in this study, we continued the investigation of quarries on the southeastern foothills of Kulen Mountain. In particular, we surveyed quarries around a $2 \mathrm{~km}$ east-west bank. As a result, sandstone quarries have been confirmed at 145 locations in total so far. At each quarry, we measured the magnetic susceptibility and step height. On the basis of these results, we deduced the locations of the seven quarrying Areas $\mathrm{A}+\mathrm{B}, \mathrm{C}+\mathrm{D}, \mathrm{E}, \mathrm{F}$ and $\mathrm{G}$ predicted by Uchida et al. $(1998,2007)$. These results clarify that sandstone quarrying started around the eastern end of the bank and quarrying then moved counterclockwise from the east side to the north side of the bank. 


\section{Acknowledgements}

This research was financially supported in part by Grants-in-Aid for Scientific Research of the Japan Society for the Promotion of Science (Uchida: no. 23401001) and Waseda University Grants for Special Research Projects (Uchida: no. 2016B-137). We wish to thank members of the Japanese government team for safeguarding Angkor and for their kind help during this research. We would like to thank Editage for the English language editing.

\section{Conflicts of Interest}

The authors declare no conflicts of interest regarding the publication of this paper.

\section{References}

Boulbet, J. (1979). Le Phnom Kulen et sa région. Collection de Textes et Documents sur I'Indochine, École Franç. d'Extrême-Orient.

Carò, F., \& Im, S. (2012). Khmer Sandstone Quarries of Kulen Mountain and Koh Ker: A Petrographic and Geochemical Study. Journal of Archaeological Science, 39, 1445-1454. https://doi.org/10.1016/j.jas.2012.01.007

Delaporte, L. (1880). Voyage au Cambodge. L'architecture khmer. Delagange.

Delvert, L. J. (1963). Recherches sur l'érosion des grès des monuments d'Angkor. Bulletin de l'Ecole française d'Extrême-Orient, 51, 453-534.

https://doi.org/10.1016/j.jas.2012.01.007

ESCAP (1993). Atlas of Mineral Resources of the ESCAP Region: Geological Map of Cambodia; Mineral Resources Map of Cambodia (Vol. 10). United Nations.

Evans, D. (2016). Airborne Laser Scanning as a Method for Exploring Long-Term Socio-Ecological Dynamics in Cambodia. Journal of Archaeological Science, 74, 164-175. https://doi.org/10.1016/j.jas.2016.05.009

Garnier, F. (1873). Voyage d'exploration en Indochine: effectué pendant les année 1866, 1867 et 1868 , Hachette.

Mantajat, N., \& Hinthong, C. (1990). Geological Map of Thailand, Scale 1:2,500,000. Geological Survey Division, Department of Mineral Resources.

Meesook, A. (2011). Cretaceous. In M. F. Ridd et al. (Eds.), The Geology of Thailand (pp. 169-184). New York: Geological Society. https://doi.org/10.1144/GOTH.8

Meesook, A., Suteethorn, V., Chaodumrong, P., Teerarungsigul, N., Sardsud, A., \& Wongprayoon, T. (2002). Mesozoic Rocks of Thailand: A Summary (pp. 82-94). Proceedings of the Symposium on Geology of Thailand.

Tien, P. C., An, L. D., Bach, L. D., Bac, D. D., Vongdara, B., Phengthavongsa, B., Danh, T., Dy, N. D., Dung, H. T., Hai, T. Q., Khuc, V., Kun, S. C., Long, P. D., Ly, M. N., My, N. Q., Ngan, P. K., Ngoc, N., Ratanavong, N., Quoc, N. K., Quyen, N. V., Aphaymani, S. D., Thanh, T. D., Tri, T. V., Truyen, M. T., \& Xay, T. S. (1990). Geology of Cambodia, Laos and Vietnam. Explanatory Note to the Geological Map of Cambodia, Laos and Vietnam at 1:1,000,000 Scale. The Geological Survey of Vietnam.

Uchida, E., \& Shimoda, I. (2013). Quarries and Transportation Routes of Angkor Monument Sandstone Blocks. Journal of Archaeological Science, 40, 1158-1164. https://doi.org/10.1016/j.jas.2012.09.036

Uchida, E., Cunin, O., Shimoda, I., Suda, C., \& Nakagawa, T. (2003). The Construction 
Process of the Angkor Monuments Elucidated by the Magnetic Susceptibility of Sandstone. Archaeometry, 45, 221-232. https://doi.org/10.1111/1475-4754.00105

Uchida, E., Cunin, O., Suda, C., Ueno, A., \& Nakagawa, T. (2007). Consideration on the Process and the Sandstone Quarries during the Angkor Period Based on the Magnetic Susceptibility. Journal of Archaeological Science, 34, 924-935.

https://doi.org/10.1016/j.jas.2006.09.015

Uchida, E., Ito, K., \& Shimizu, N. (2010). Provenance of the Sandstone Used in the Construction of the Khmer Monuments in Thailand. Archaeometry, 52, 550-574. https://doi.org/10.1111/j.1475-4754.2009.00505.x

Uchida, E., Ogawa, Y., \& Nakagawa, T. (1998). The Stone Materials of the Angkor Monuments, Cambodia: The Magnetic Susceptibility and the Orientation of the Bedding Plane of the Sandstone. Journal of Mineralogy, Petrology and Economic Geology, 93, 411-426. https://doi.org/10.2465/ganko.93.411

Uchida, E., Shimoda, I., \& Shimoda, M. (2013). Consideration of the Construction Period of the Khmer Temples along the East Royal Road to Preah Khan of Kompong Svay and the Provenance of Sandstone Blocks Based on Their Magnetic Susceptibility. Archaeological Discovery, 1, 37-48. https://doi.org/10.4236/ad.2013.12004

Uchida, E., Suda, C., Ueno, A., Shimoda, I., \& Nakagawa, T. (2005). Estimation of the Construction Period of Prasat Suor Prat in the Angkor Monuments, Cambodia, Based on the Characteristics of Its Stone Materials and the Radioactive Carbon Age of Charcoal Fragments. Journal of Archaeological Science, 32, 1339-1345.

https://doi.org/10.1016/j.jas.2005.03.011

Uchida, E., Tsuda, K., \& Shimoda, I. (2014). Construction Sequence of the Koh Ker Monuments in Cambodia Deduced from Chemical Composition and Magnetic Susceptibility of Its Laterites. Heritage Science, 2, 1-11. https://doi.org/10.1186/2050-7445-2-10 


\section{Appendix 1}

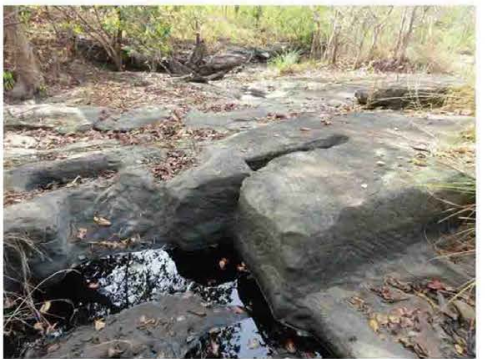

Quarry no.1

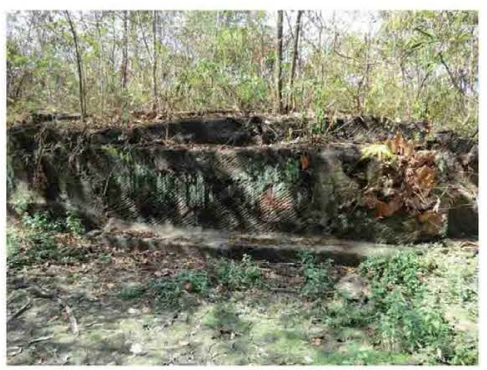

Quarry no.4

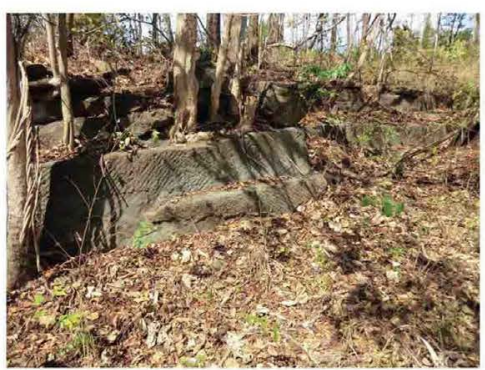

Quarry no.7

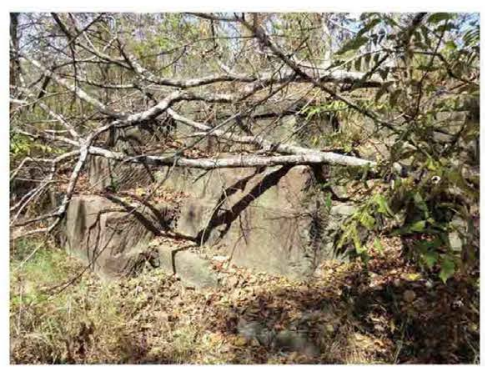

Quarry no.10

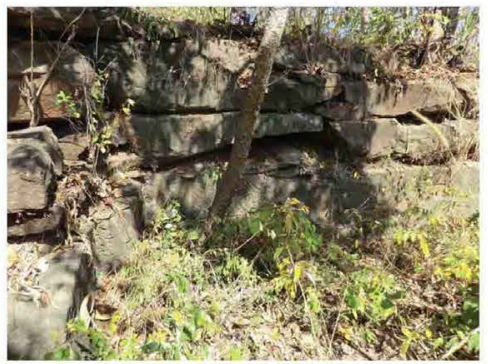

Quarry no.13

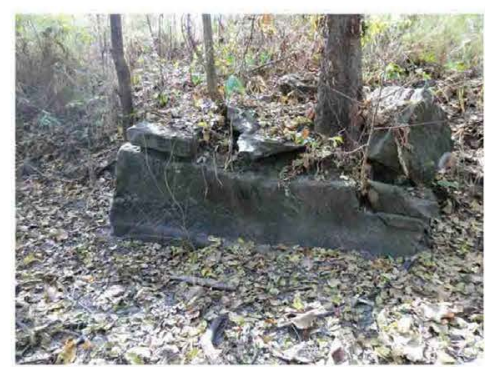

Quarry no.2

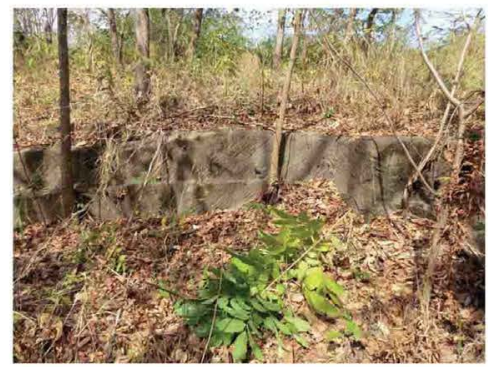

Quarry no.5

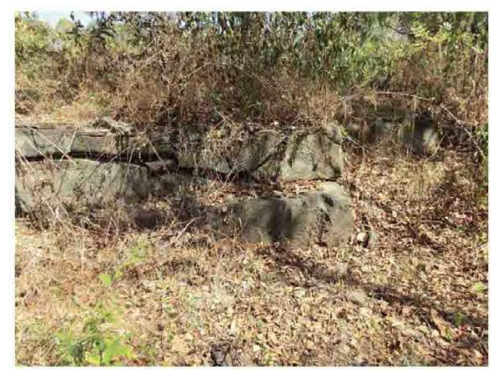

Quarry no.8

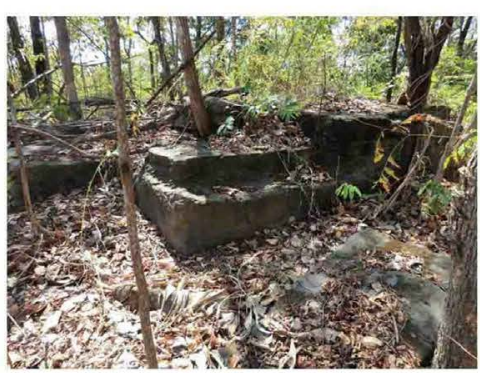

Quarry no.11

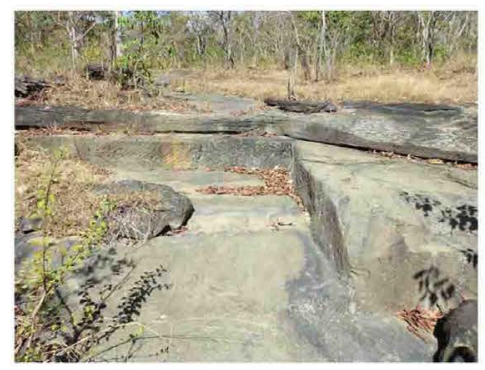

Quarry no.14

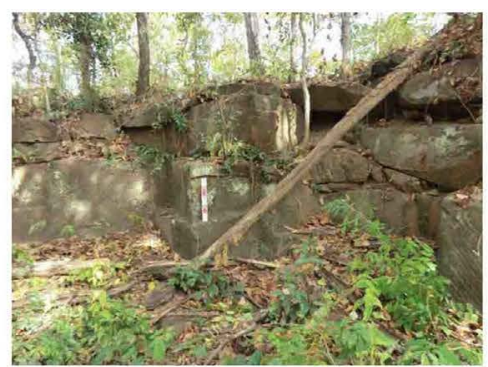

Quarry no.3

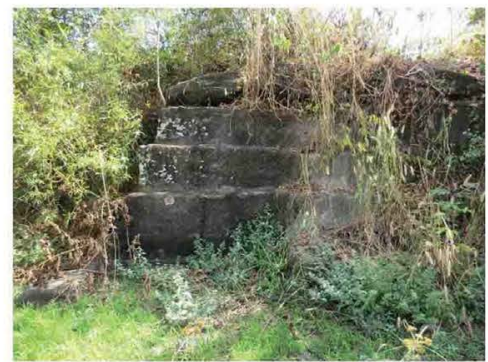

Quarry no.6

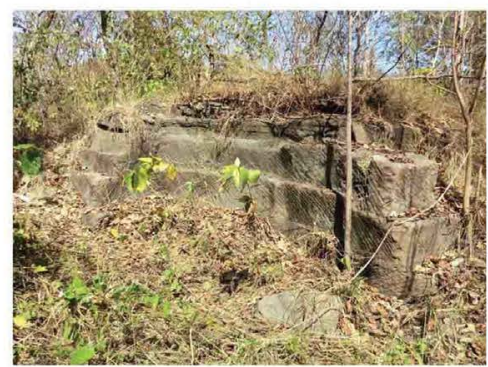

Quarry no.9

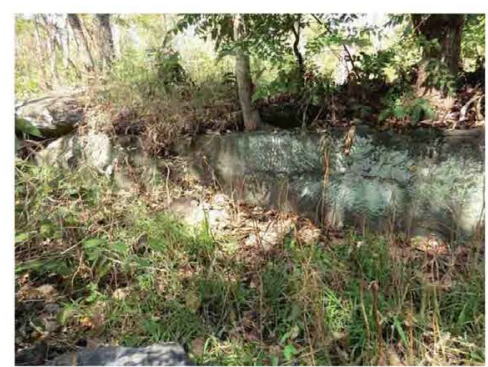

Quarry no.12

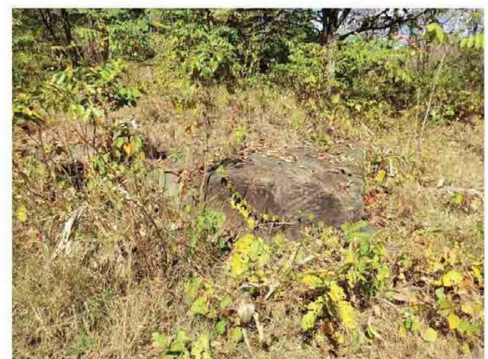

Quarry no.15 


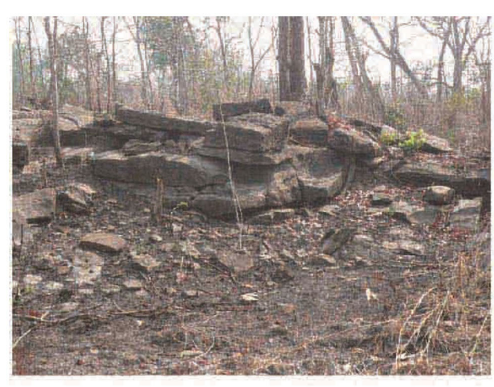

Quarry no.16

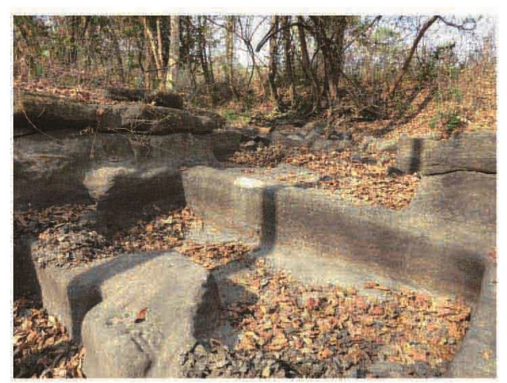

Quarry no.19

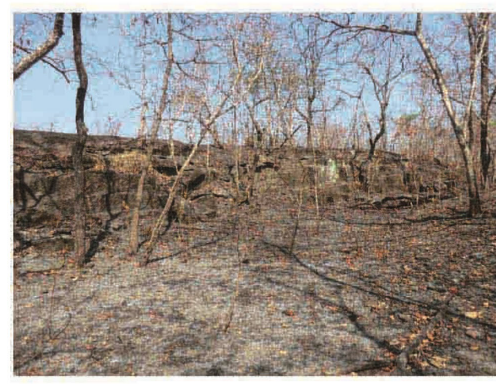

Quarry no.22

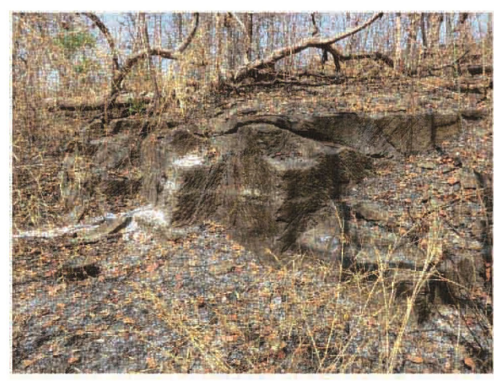

Quarry no.25

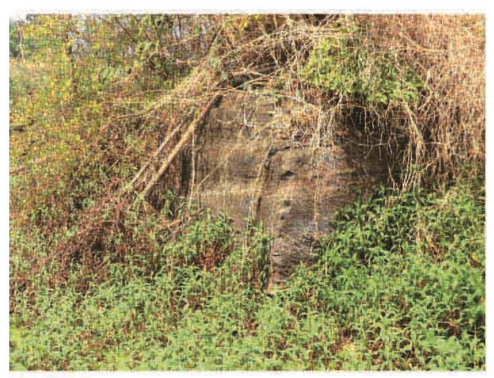

Quarry no.28

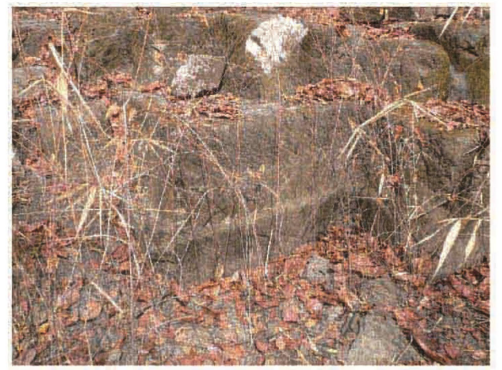

Quarry no.17

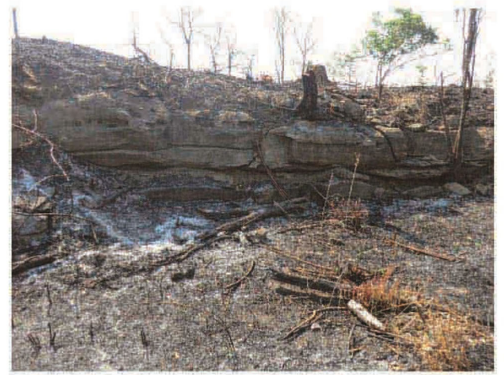

Quarry no.20

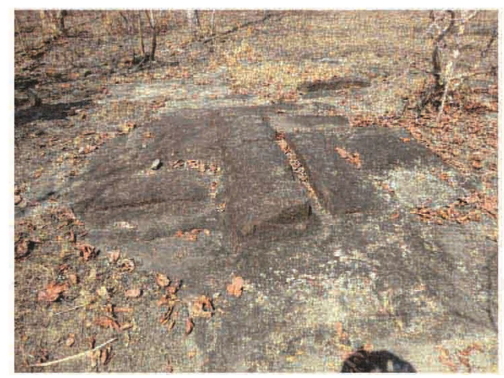

Quarry no.23

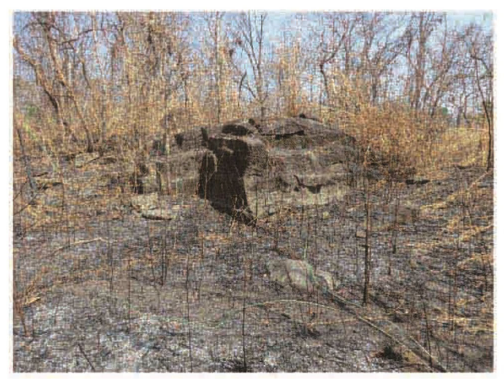

Quarry no.26

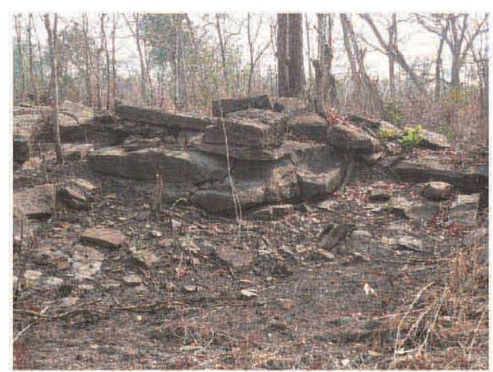

Quarry no.29

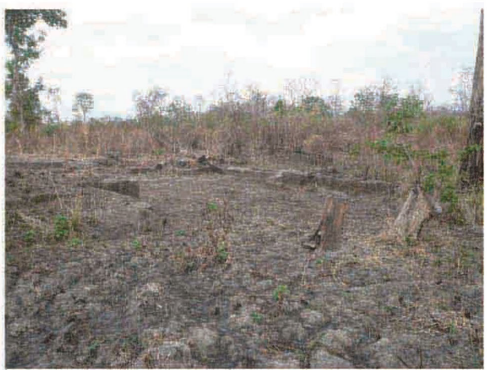

Quarry no.18

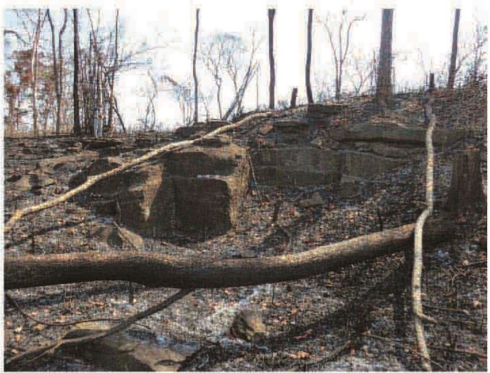

Quarry no.21

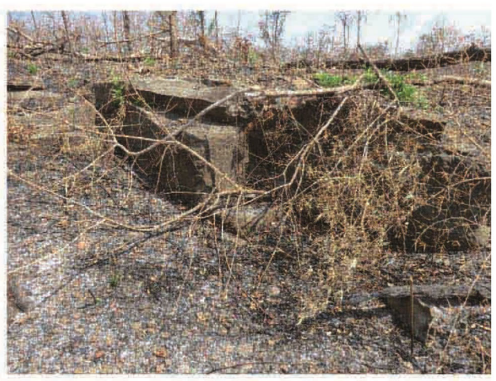

Quarry no.24

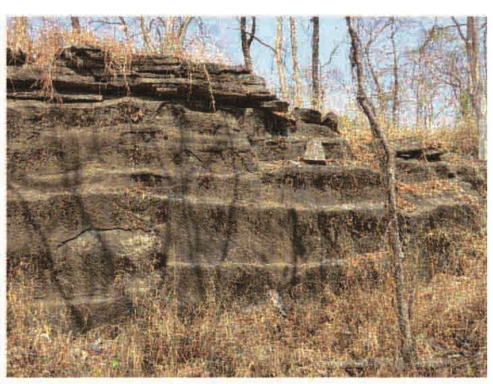

Quarry no.27

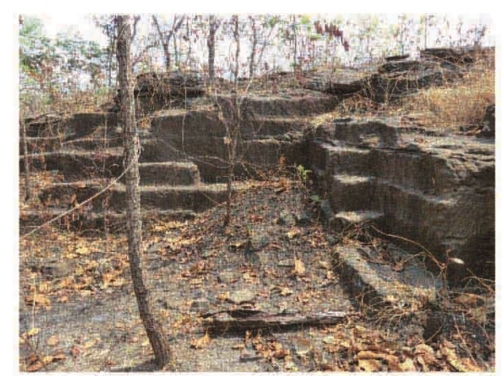

Quarry no.30 


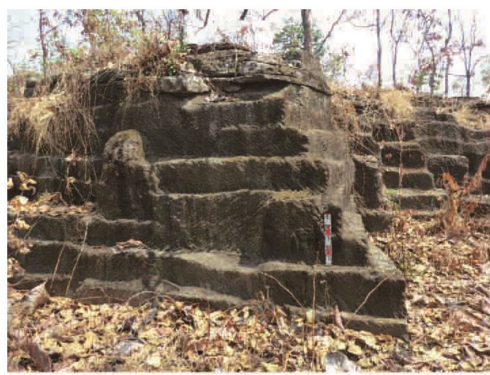

Quarry no.31

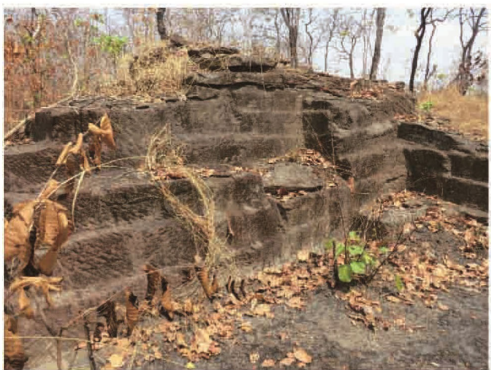

Quarry no.34

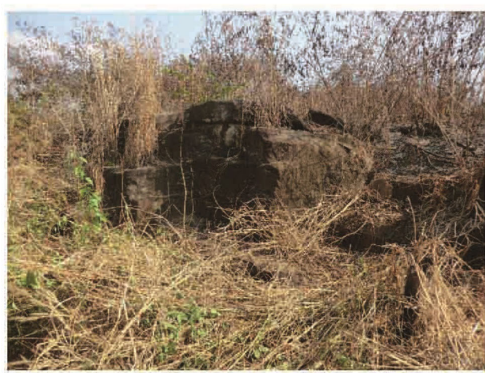

Quarry no.37

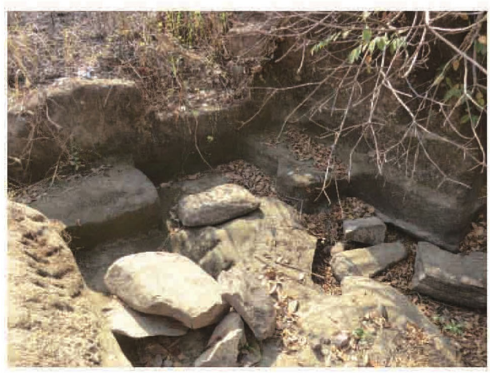

Quarry no.40

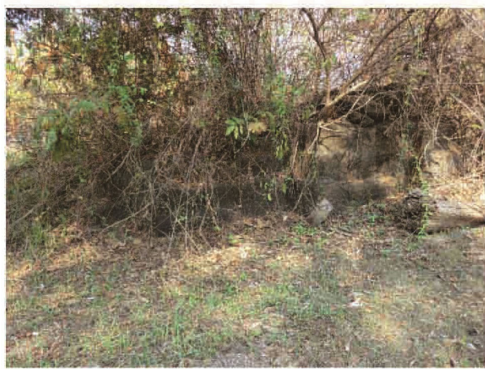

Quarry no.43

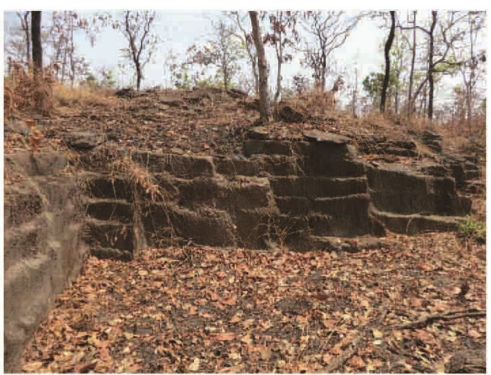

Quarry no.32

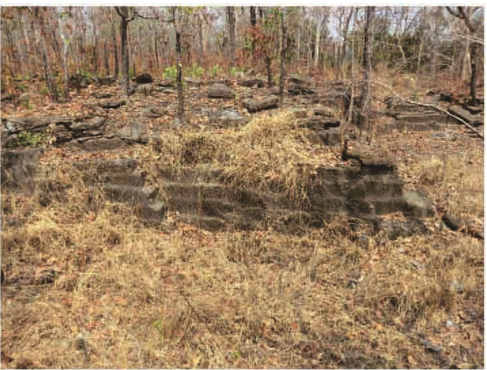

Quarry no.35

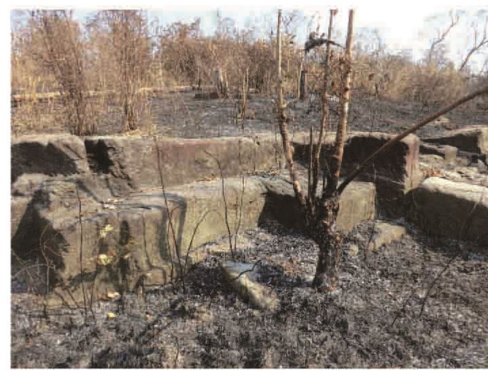

Quarry no.38

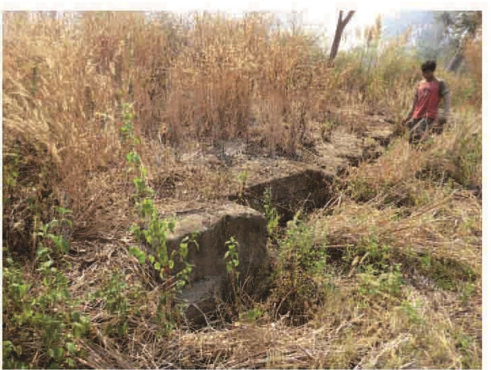

Quarry no.41

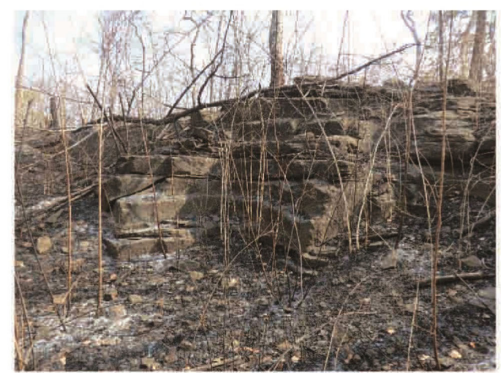

Quarry no.44

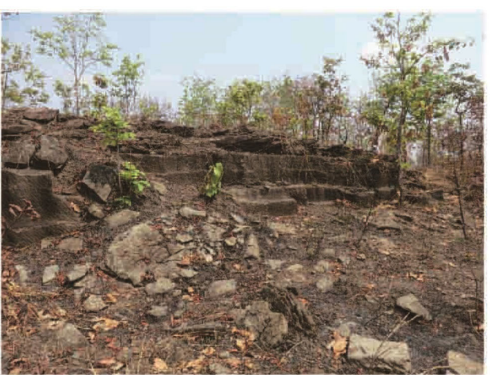

Quarry no.33

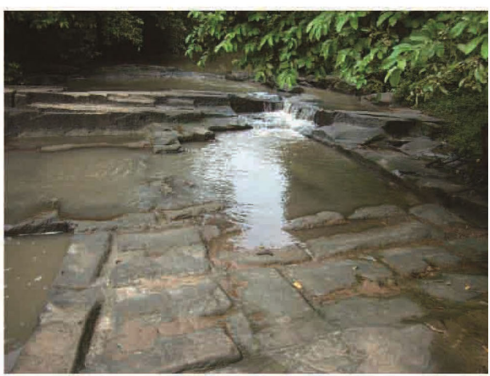

Quarry no.36

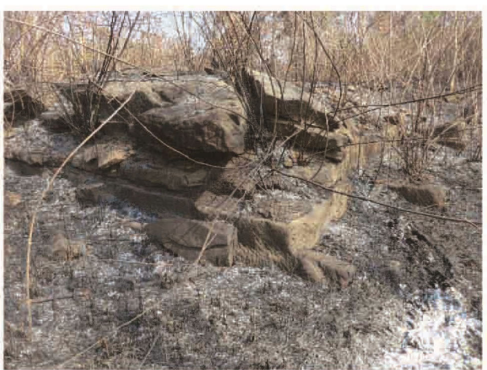

Quarry no.39

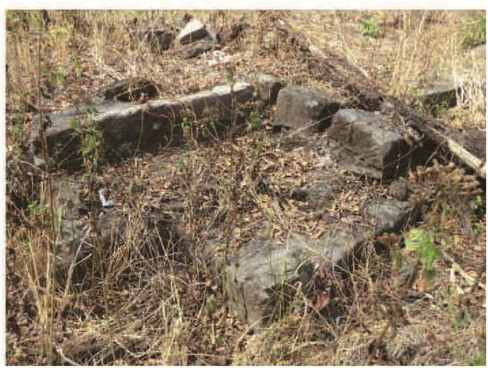

Quarry no.42

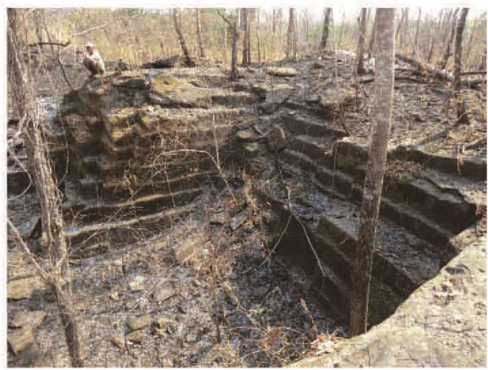

Quarry no.45 


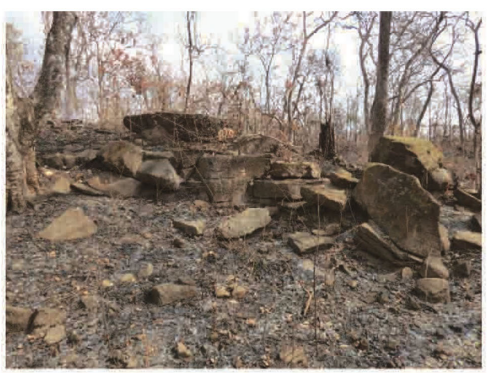

Quarry no.46

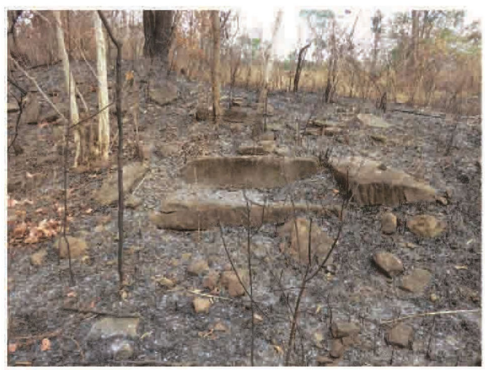

Quarry no.49

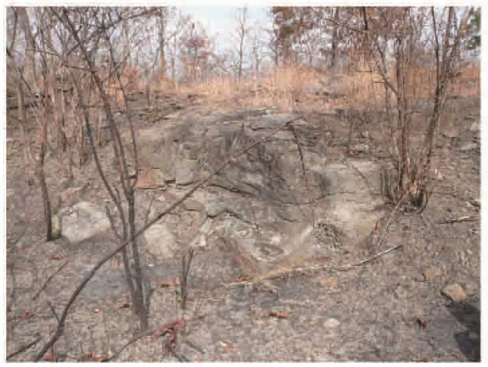

Quarry no.52

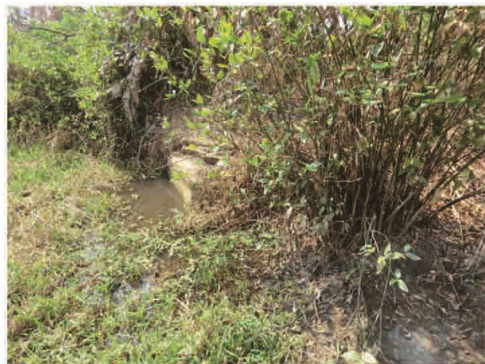

Quarry no.55

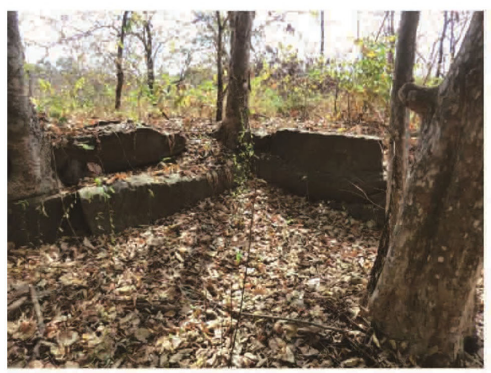

Quarry no.58

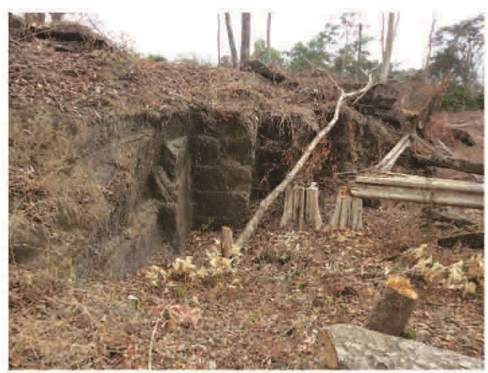

Quarry no.47

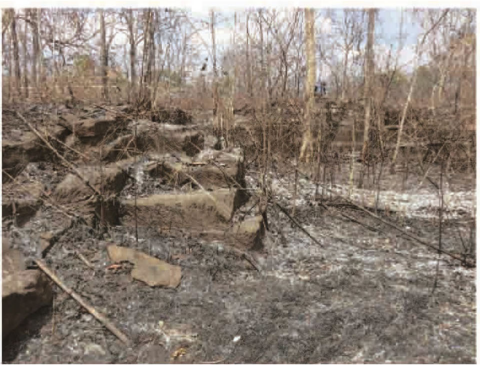

Quarry no.50

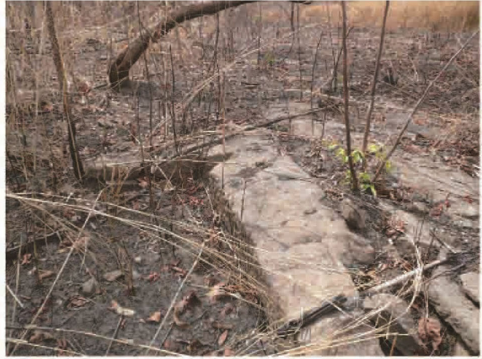

Quarry no.53

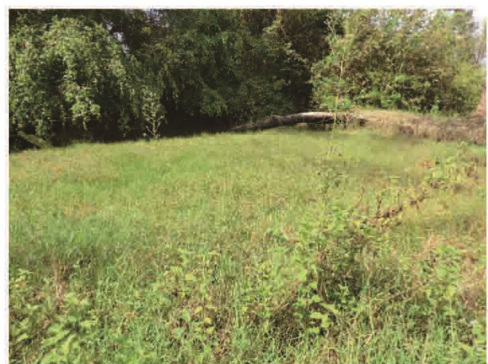

Quarry no.56

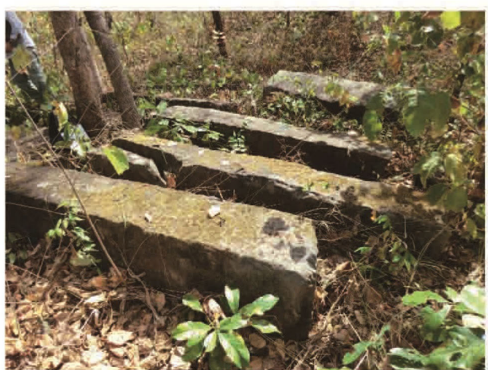

Quarry no.59

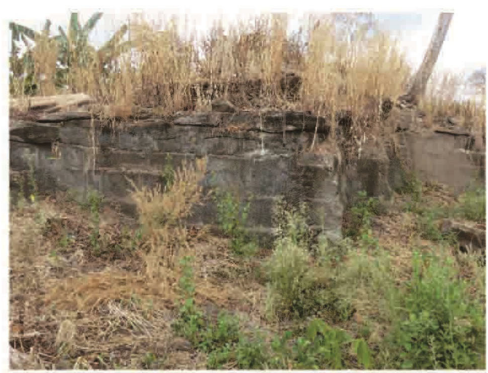

Quarry no.48

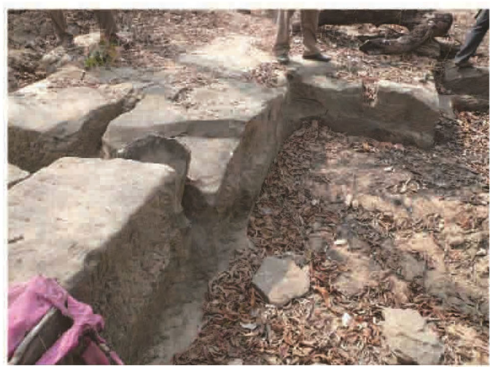

Quarry no.51

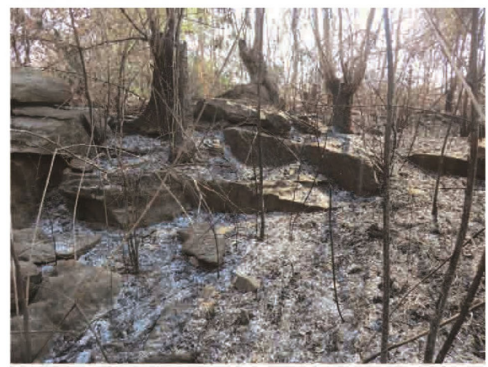

Quarry no.54

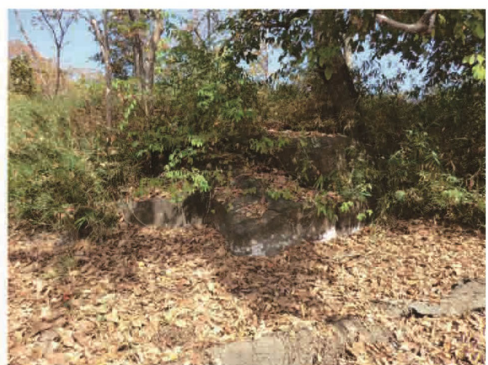

Quarry no.57

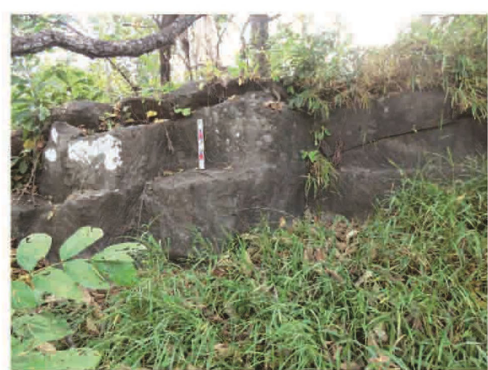

Quarry no.60 


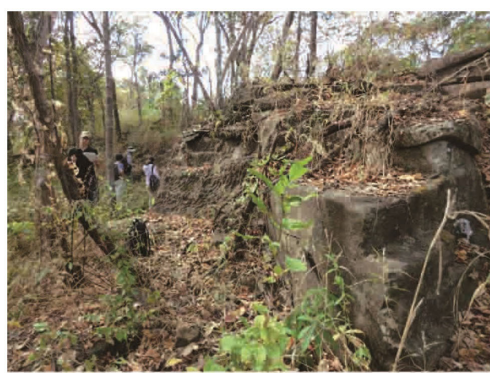

Quarry no.61

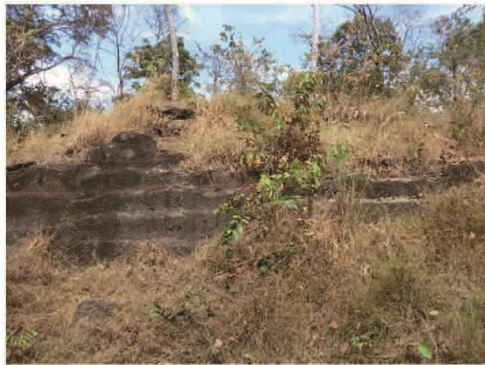

Quarry no.64

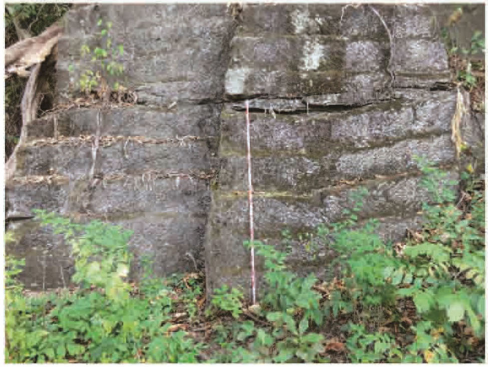

Quarry no.67

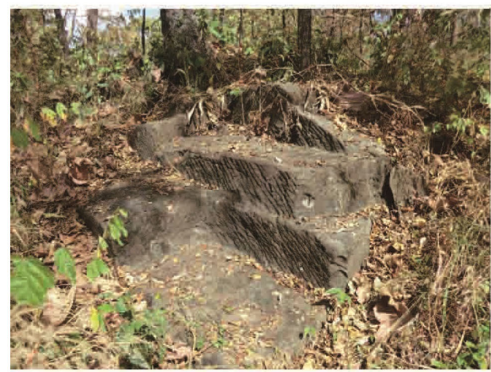

Quarry no.70

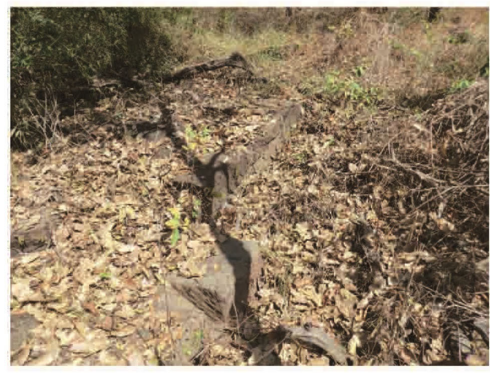

Quarry no.73

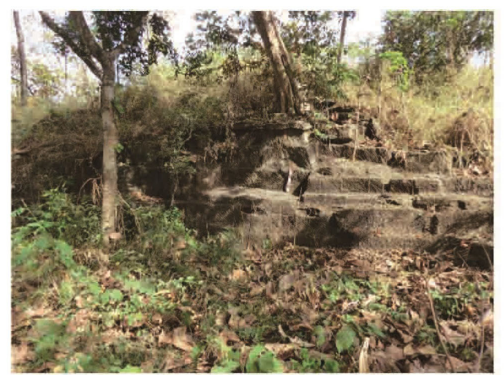

Quarry no.62

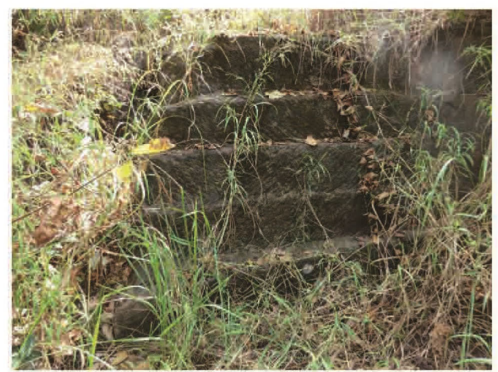

Quarry no.65

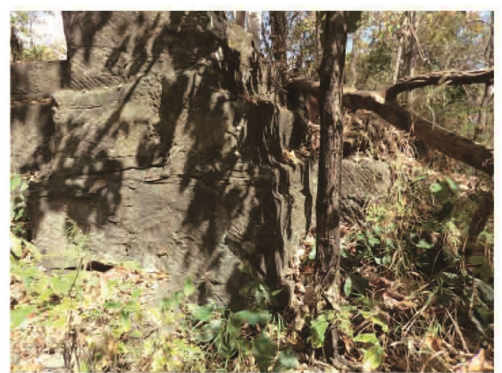

Quarry no.68

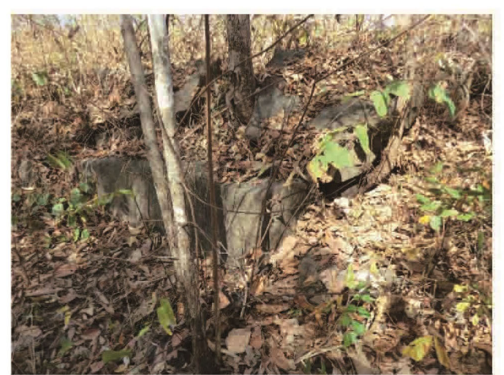

Quarry no.71

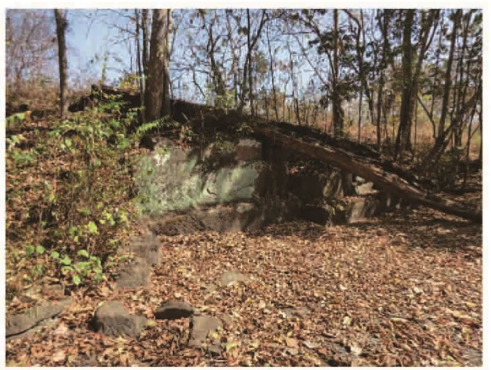

Quarry no.74

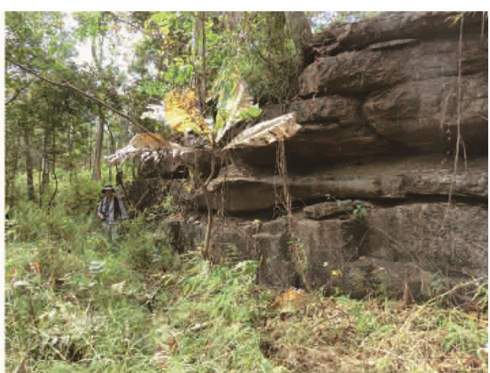

Quarry no.63

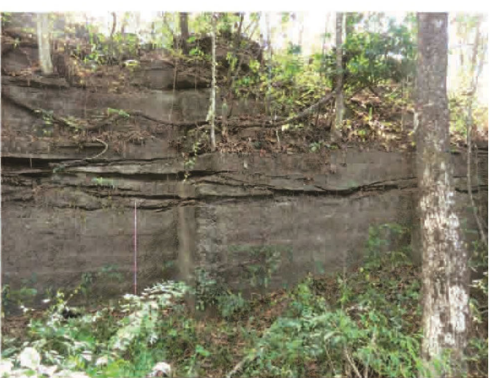

Quarry no.66

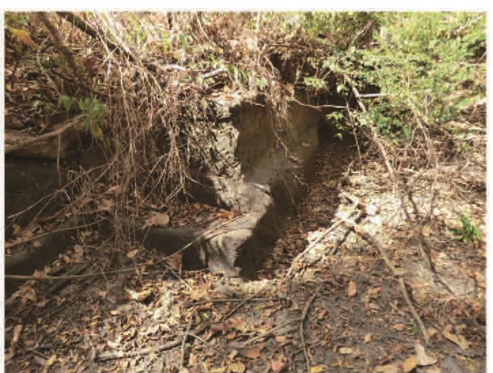

Quarry no.69

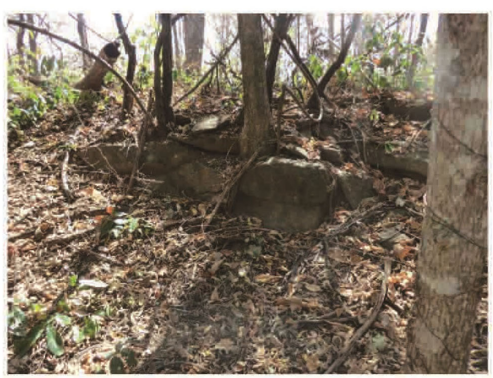

Quarry no.72

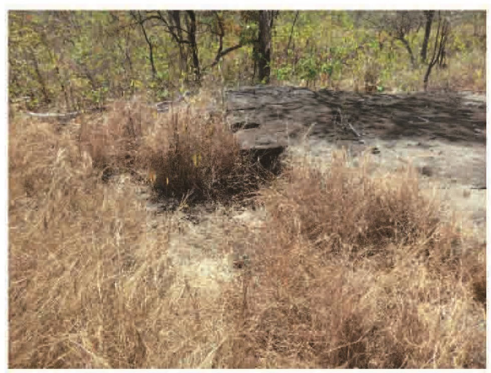

Quarry no.75 


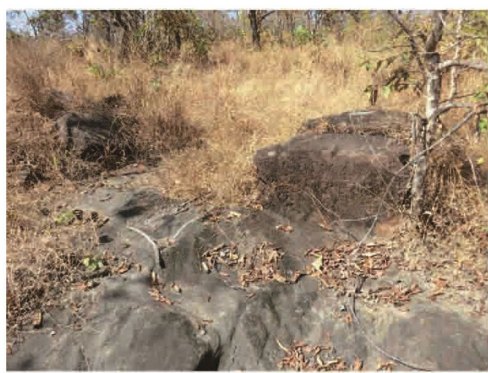

Quarry no.76

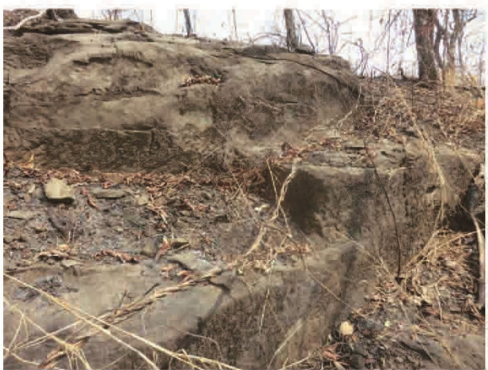

Quarry no.79

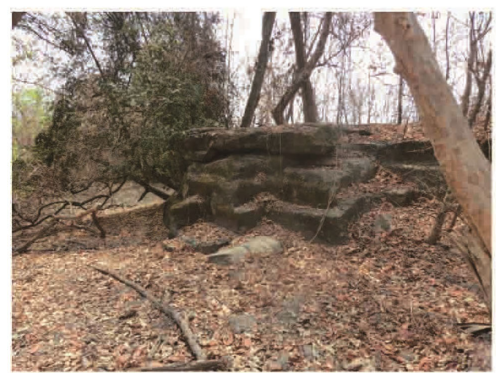

Quarry no.82

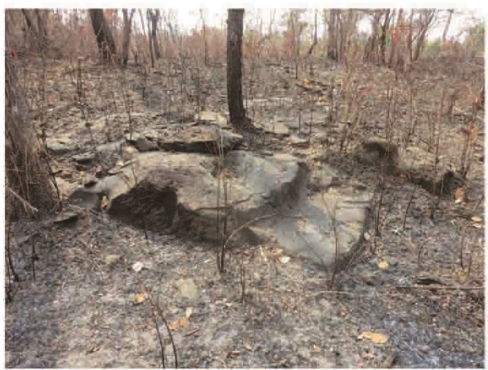

Quarry no.85

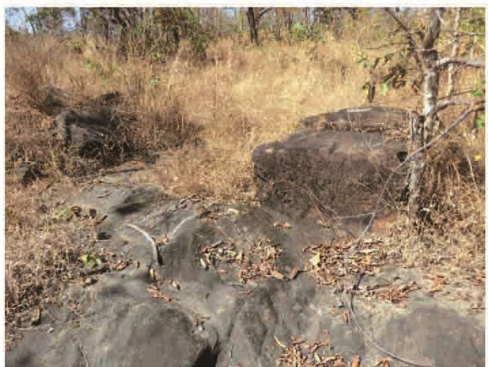

Quarry no.88

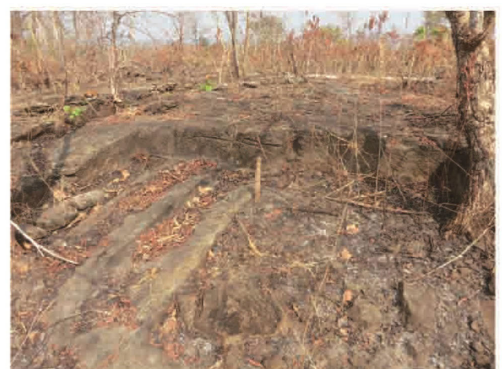

Quarry no.77

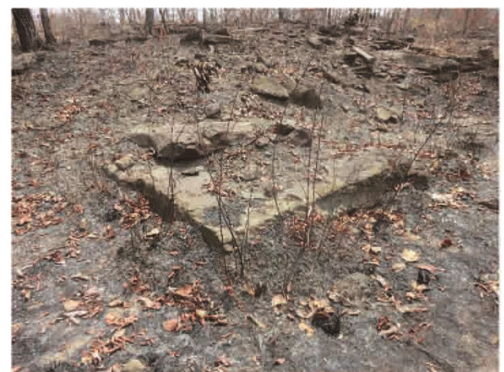

Quarry no.80

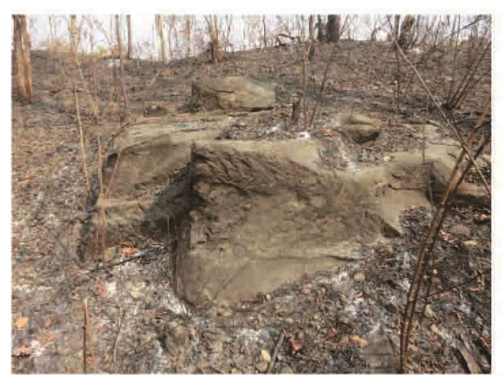

Quarry no.83

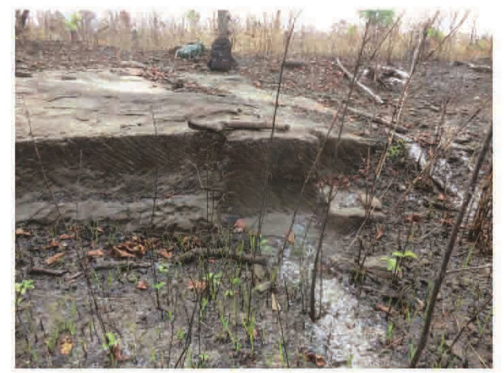

Quarry no.86

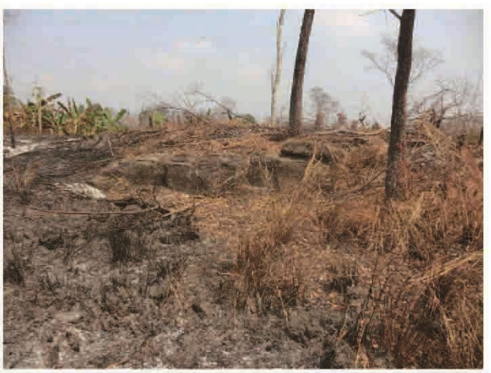

Quarry no.89

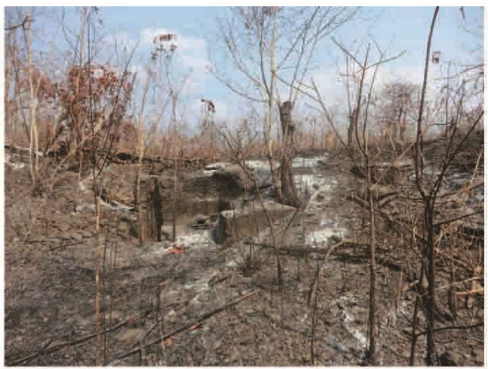

Quarry no.78

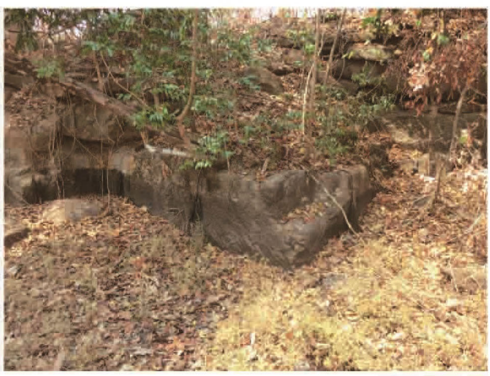

Quarry no.81

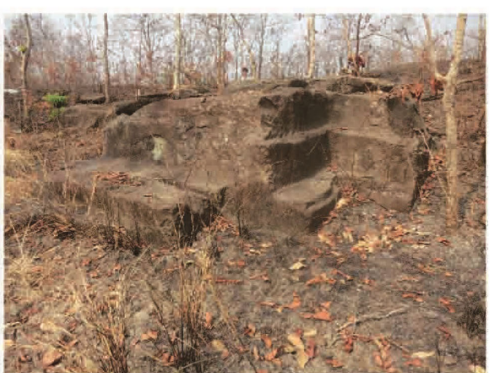

Quarry no.84

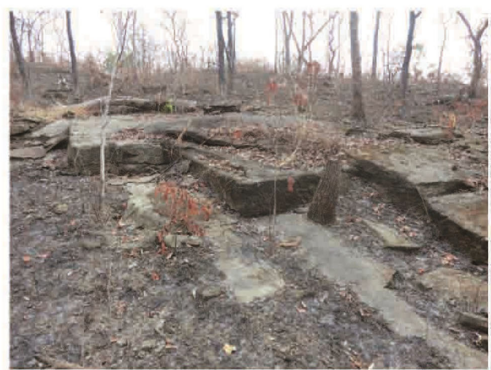

Quarry no.87

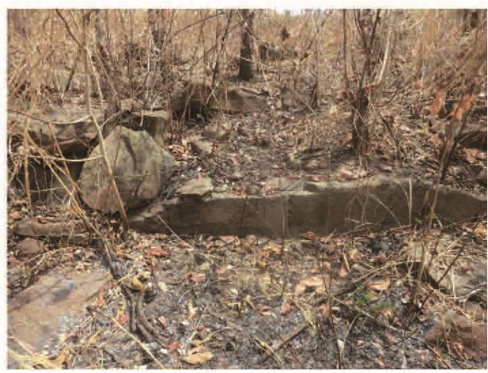

Quarry no.90 


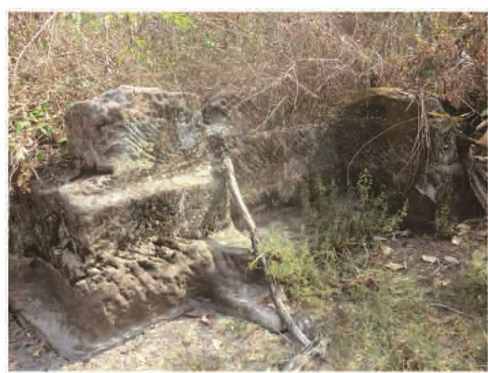

Quarry no.91

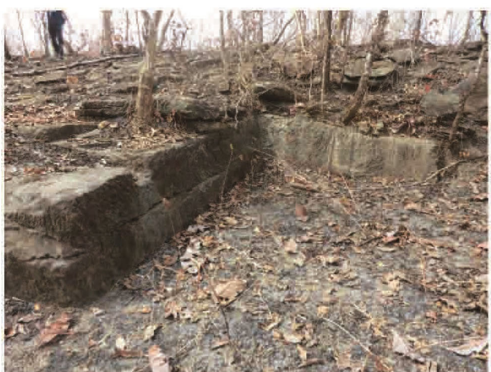

Quarry no.94

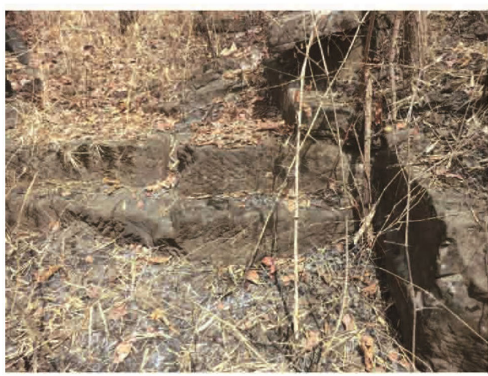

Quarry no.97

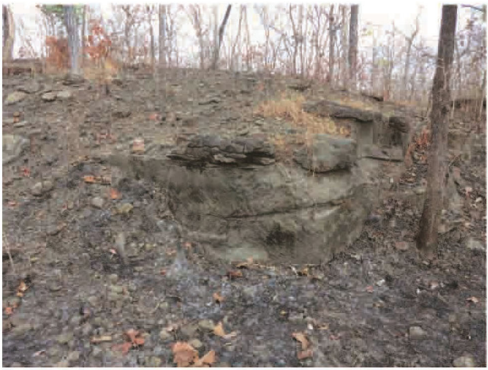

Quarry no.100

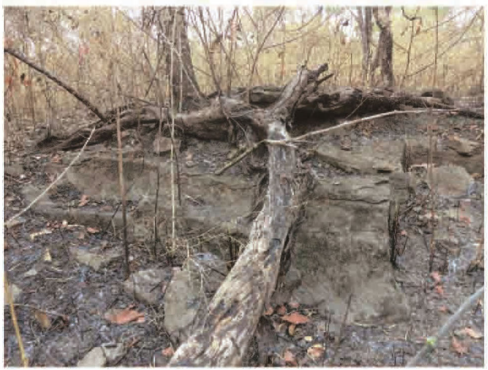

Quarry no.103

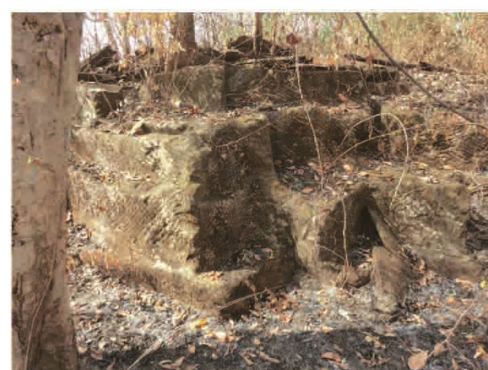

Quarry no.92

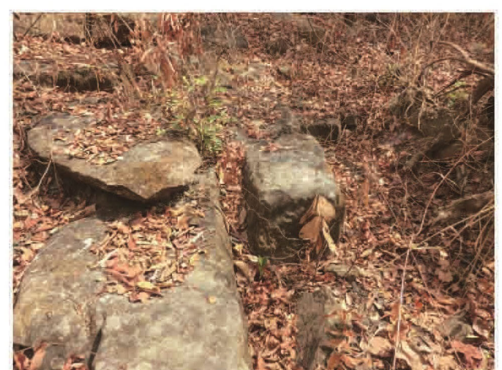

Quarry no.95

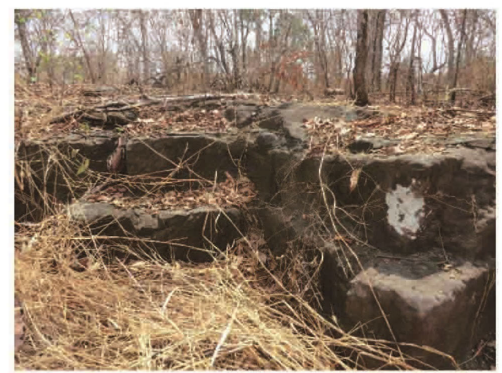

Quarry no. 98

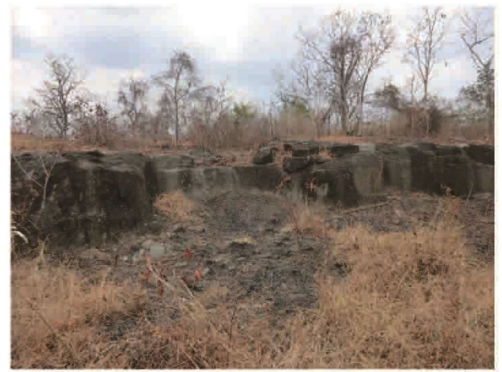

Quarry no.101

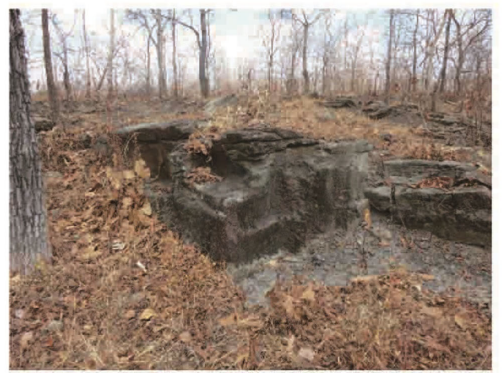

Quarry no.104

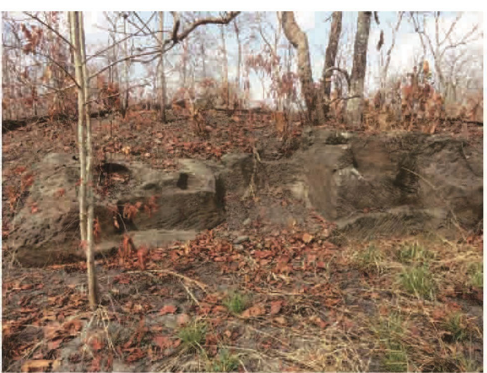

Quarry no.93

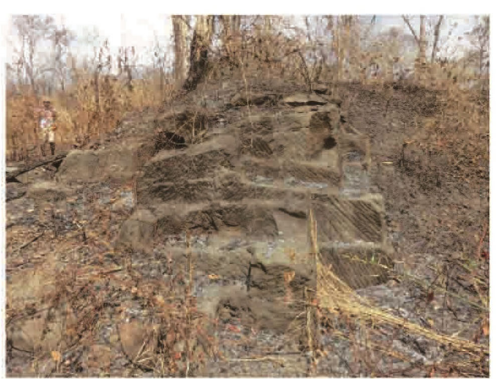

Quarry no.96

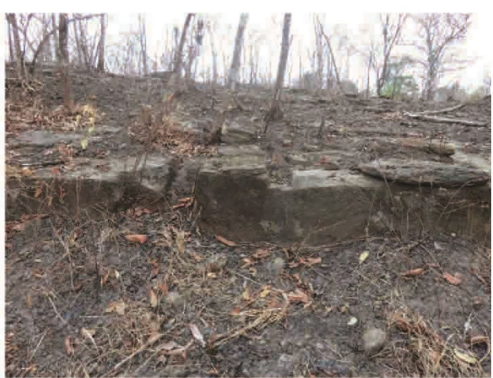

Quarry no.99

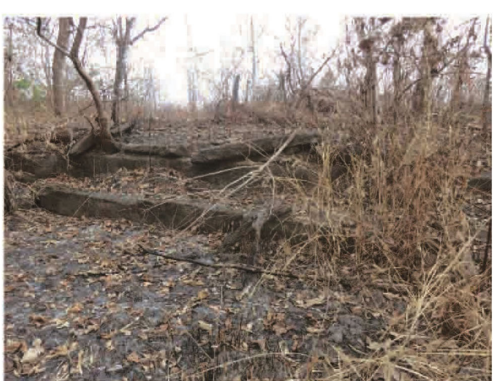

Quarry no.102

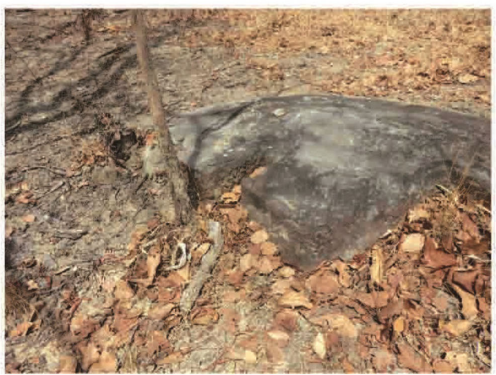

Quarry no.105 


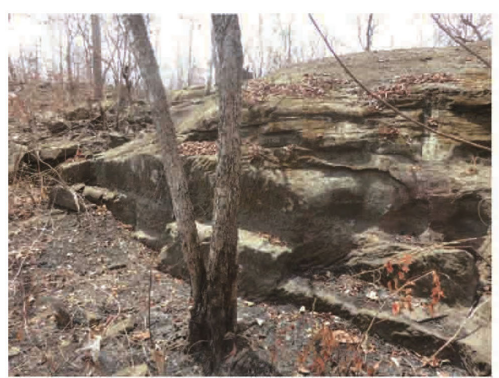

Quarry no.106

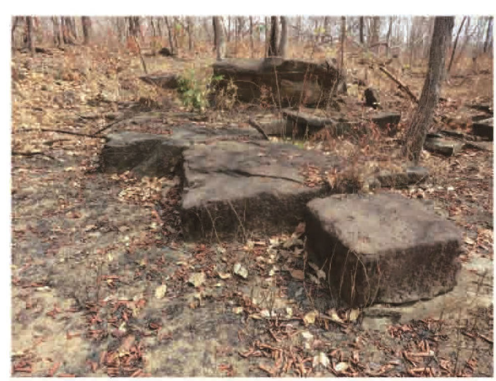

Quarry no.109

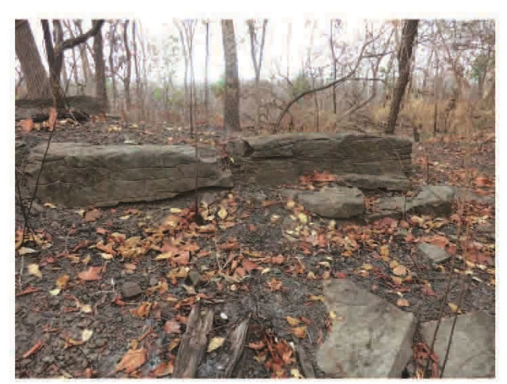

Quarry no.112

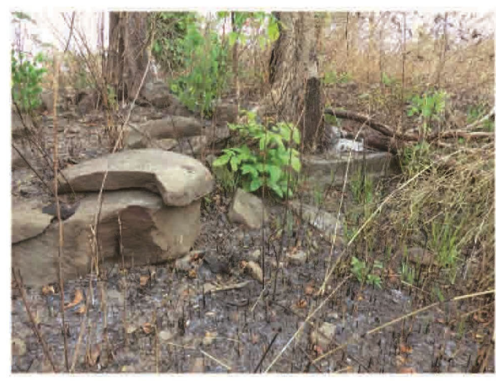

Quarry no.115

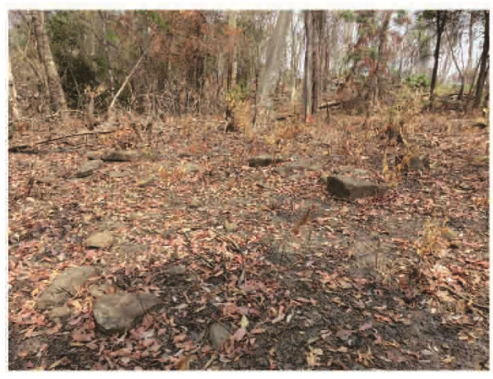

Quarry no.118

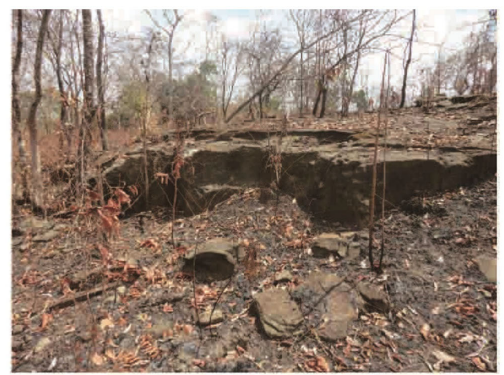

Quarry no.107

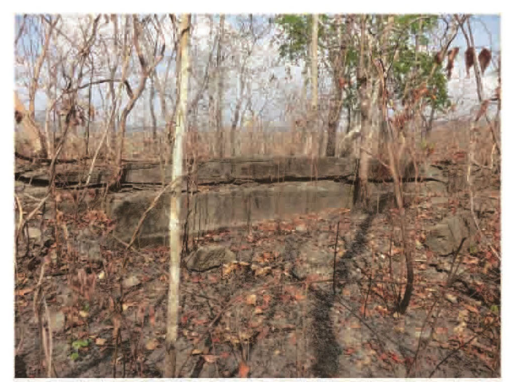

Quarry no.110

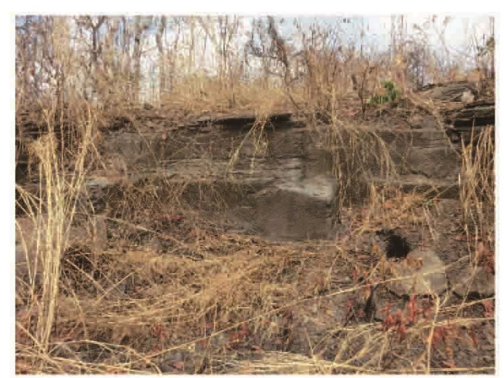

Quarry no.113

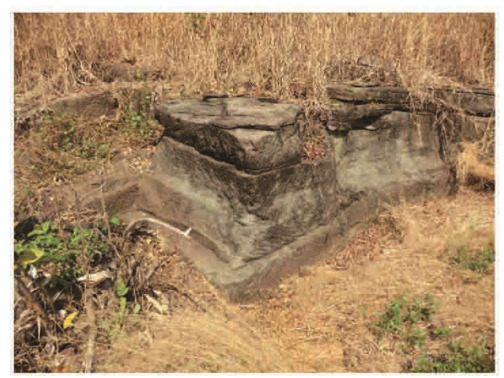

Quarry no.116

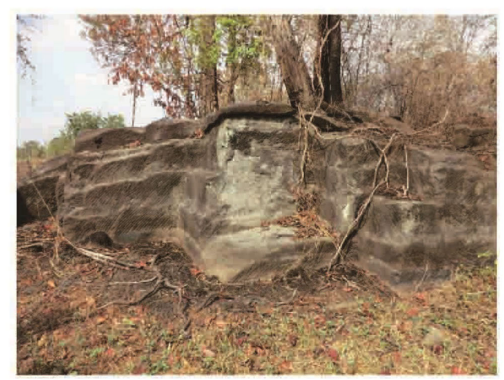

Quarry no.119

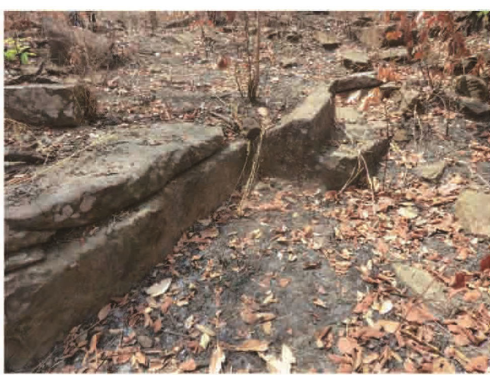

Quarry no.108

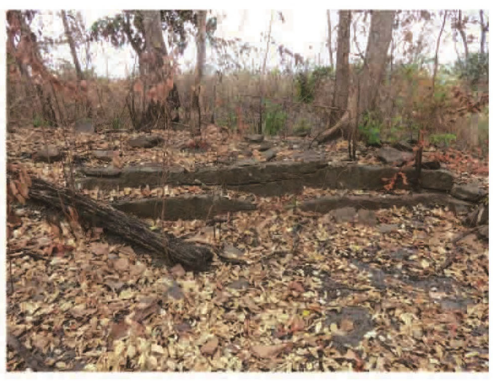

Quarry no.111

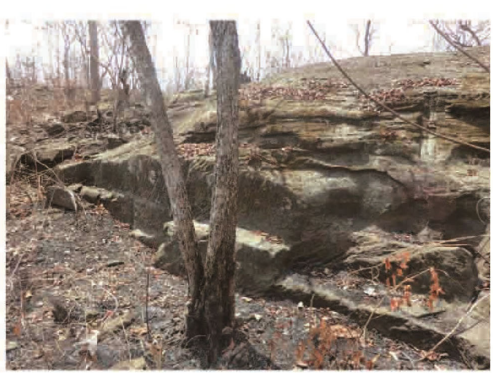

Quarry no.114

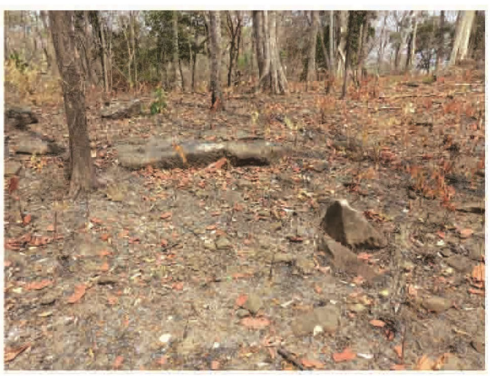

Quarry no.117

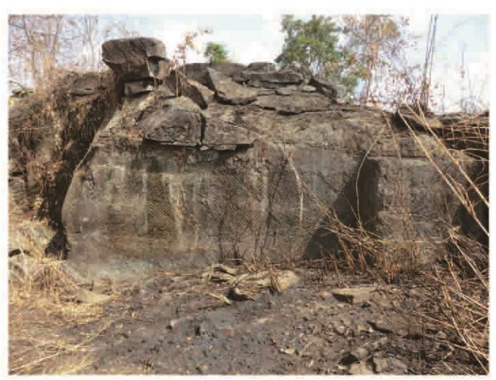

Quarry no.120 


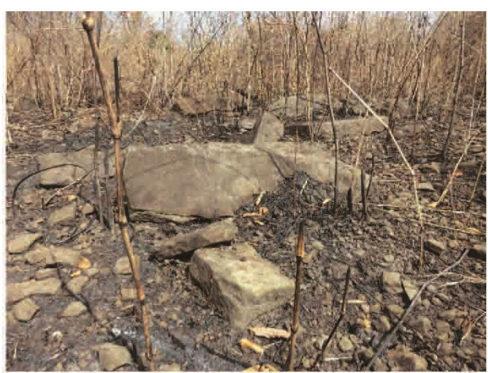

Quarry no.121

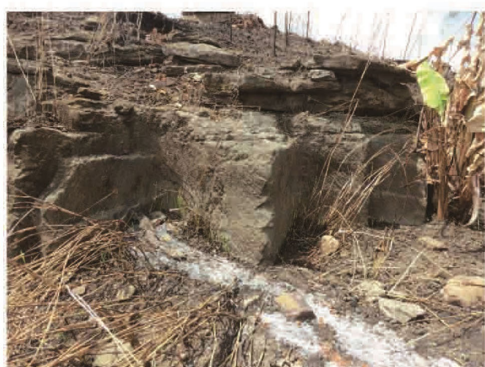

Quarry no.124

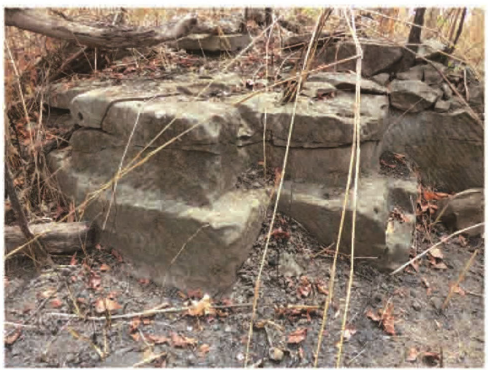

Quarry no.127

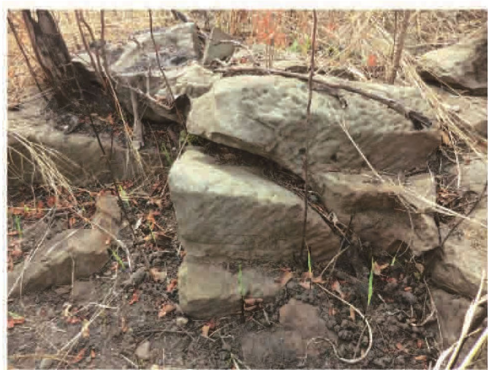

Quarry no.130

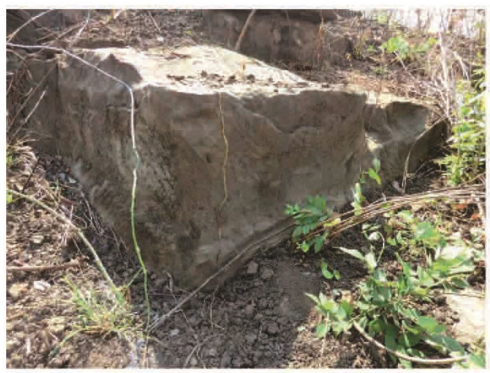

Quarry no.133

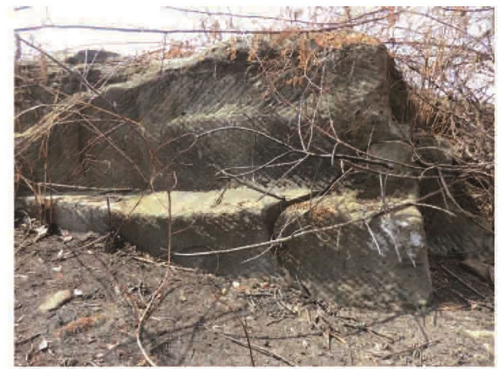

Quarry no.122

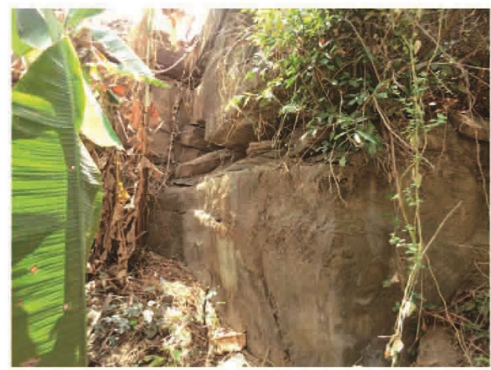

Quarry no.125

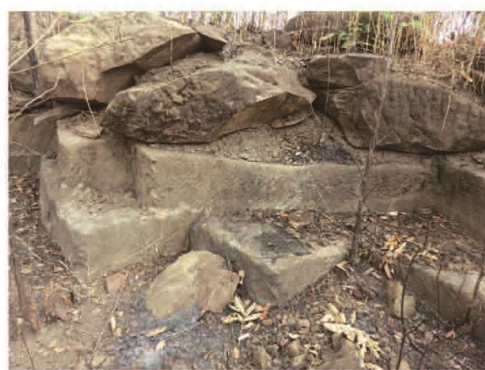

Quarry no.128

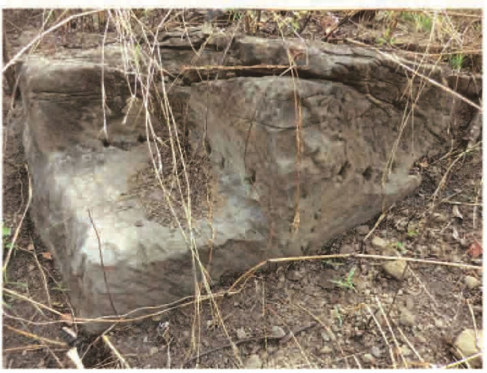

Quarry no.131

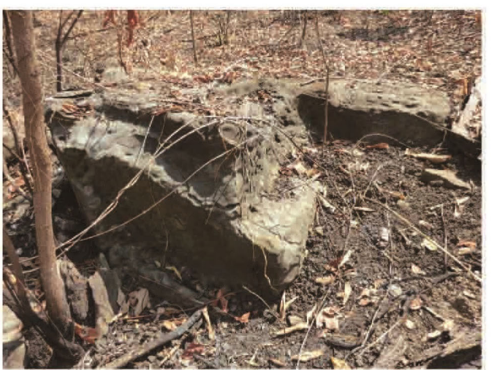

Quarry no.134

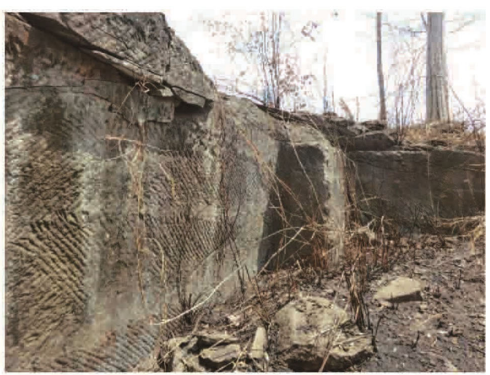

Quarry no.123

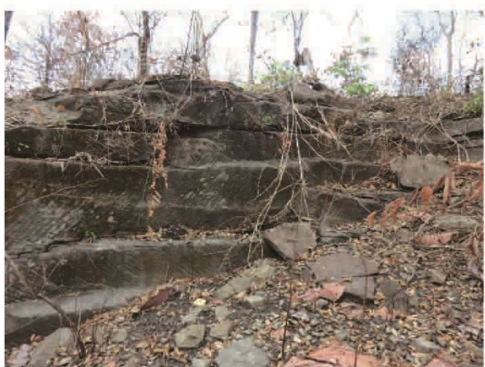

Quarry no.126

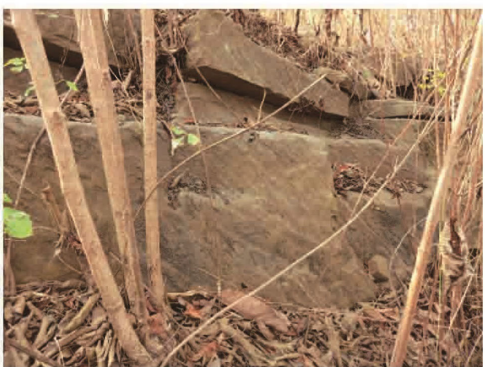

Quarry no.129

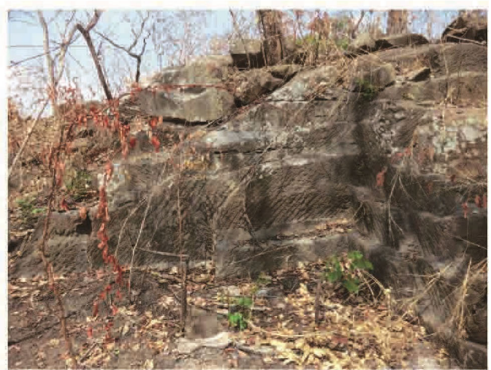

Quarry no.132

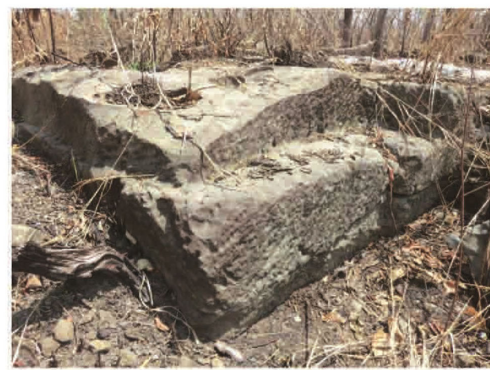

Quarry no.135 


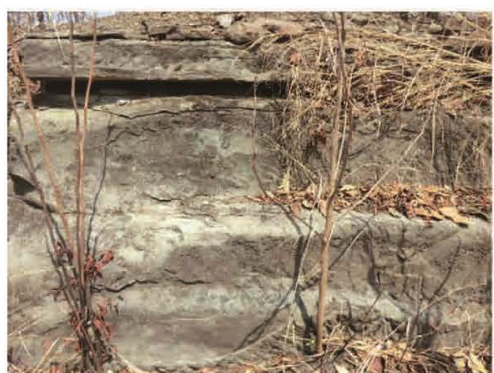

Quarry no.136

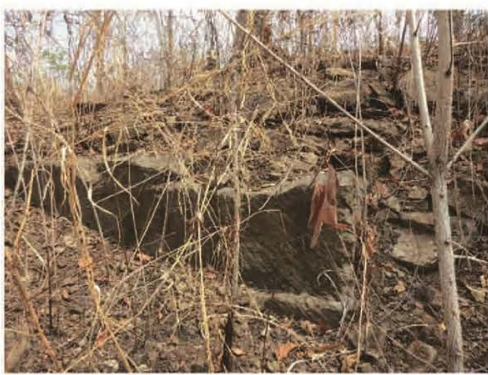

Quarry no.139

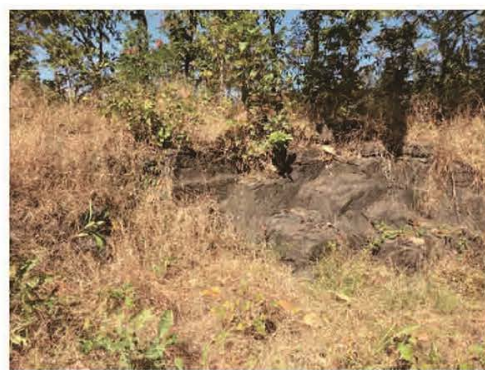

Quarry no. 142

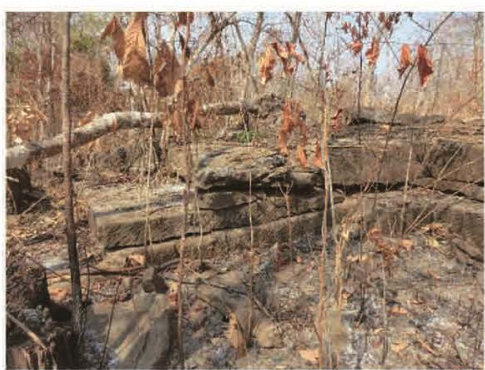

Quarry no.145

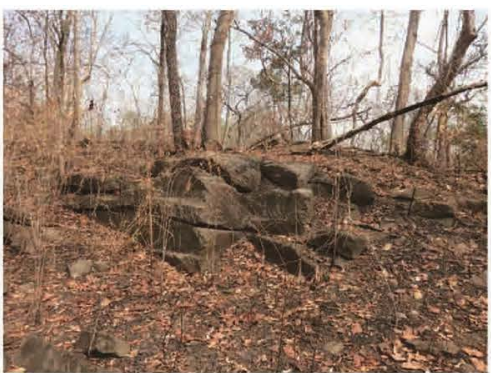

Quarry no.137

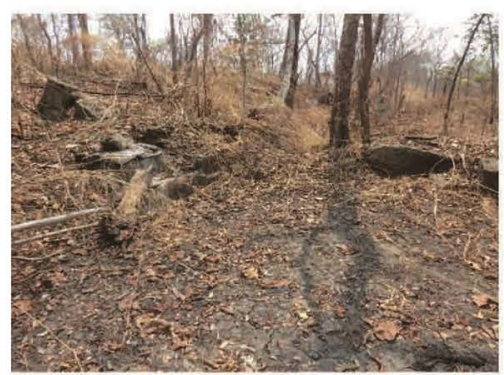

Quarry no.140

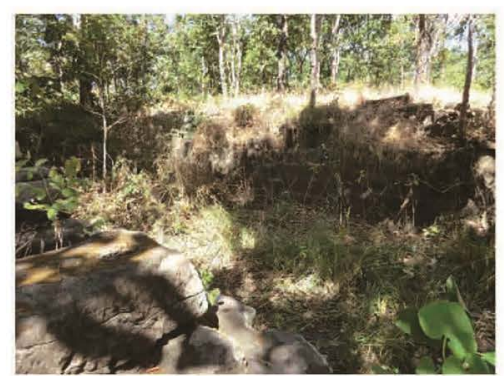

Quarry no.143

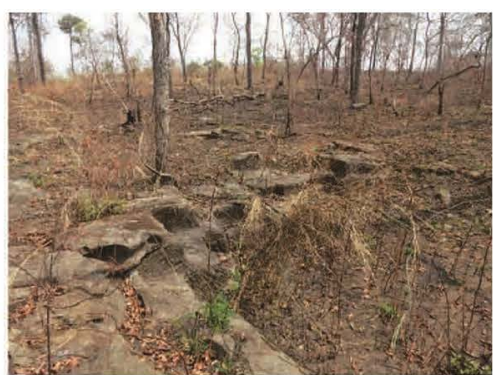

Quarry no.138

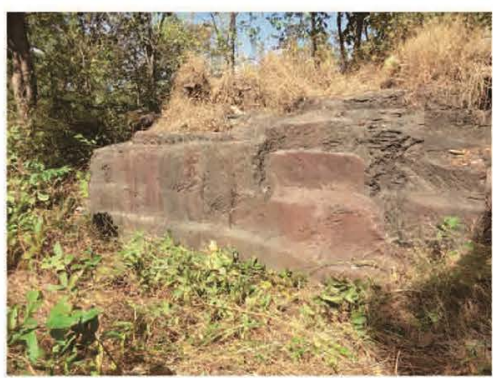

Quarry no.141

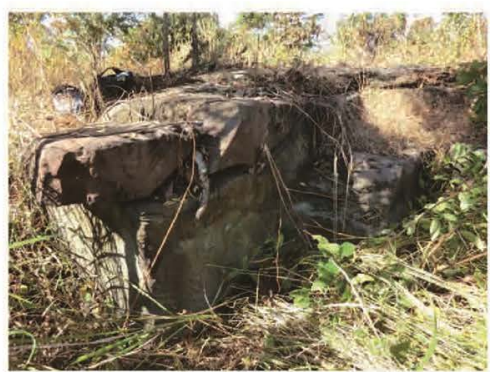

Quarry no.144

Figure A. Photographs indicating the 145 ancient sandstone quarries confirmed in this research. 